\title{
Liberalization, Corporate Governance, and the Performance of Newly Privatized Firms
}

By: Narjess Boubakri, Jean-Claude Cosset, and Omrane Guedhami

William Davidson Working Paper Number 419

December 2001 


\title{
Liberalization, Corporate Governance and the Performance of N eWly Privatized Firms*
}

\author{
N ARJESS BOUBAKRI \\ Faculte des sciences del'administration \\ Universite Laval \\ Quebec, P.Q. , Canada G1K 7P4 \\ Narjess.Boubakri@fsa.ulaval.ca \\ Jean-Claude Cosset \\ Faculte des sciences del'administration \\ Universite Laval \\ Quebec, P.Q. , Canada G1K 7P4 \\ Jean-Claude.Cosset@fas.ulaval.ca \\ OMRANE G UEDHAM I \\ Faculte des sciences del'administration \\ Universite Laval \\ Quebec, P.Q. , Canada G1K 7P4 \\ Omrane.Guedhami@sa.ulaval.ca
}

Key words : Liberalization, Corporate Governance, Privatization, Performance.

\begin{abstract}
* We appreciate the helpful comments made by Terry Campbell, Sylvain Dessy, Klaus Fischer, Merlyn Foo, Lynda Khalaf, Anna Meyendorff, Bruce Shearer, Oumar Sy, Désiré Vencatachellum on previous versions of this paper. Wealso received much valuable input from seminar participants at Universite Laval, the 2001 Administrative Sciences Association of Canada's Annual Conference in London (Ontario), the 2001 PACAP/ Financial Management Association Conference in Seoul, the Third Annual Conference on "Financial Market Development in Emerging and Transition Economies" in Hong Kong, the 2001 Northern Finance Association Meeting in Halifax (N ova Scotia) and the 2001 Financial Management Association Meeting in Toronto (Canada). We are grateful to Afeikhena Jerome from the University of Ibadan (Nigeria), Udeaja Elais Anachioke (Nigeria), Mohamed Daouas from the Tunisian Central Bank, Smith Dustin from the International Monetary Fund and the Casablanca Stock Exchange (Morocco) for providing us with data. Finally, we are indebted to Martin Desrochers, Frederic Gamache, Souheil Hassine and Meissa N'Dir for excellent research assistance. All errors remain our responsibility.
\end{abstract}


William Davidson Institute Working Paper 419

\title{
Liberalization, Corporate Governance and the Performance OF NeWLy PRIVATIZEd FIRMS
}

\begin{abstract}
This paper seeks to provide an answer to the following question, namely when and how does privatization work? Using a unique sample of 201 firms headquartered in 32 developing countries, we document a significant increase in profitability, efficiency, investment and output. Next, using univariate tests, we show that corporate governance mechanisms and economic reforms and environment have an effect on the changes in operating performance. For example, we find that privatization yields better results when stock market and trade liberalizations precede it. The results of a regression analysis, across a number of specifications, indicate that economic reforms and environment as well as corporate governance variables explain the post-privatization performance changes. In particular, economic growth, control relinquishment by the government and foreign ownership are key determinants of profitability changes. We also find higher improvements in efficiency and output for firms in countries in which stock markets are more developed and where property rights are better protected and enforced. Finally, our results suggest that trade openness is an important determinant of the post-privatization increase in investment.
\end{abstract}


William Davidson Institute Working Paper 419

\section{Liberalization, Corporate Governance and the Performance of NeWLy Privatized Firms}

Several studies have recently documented a performance improvement of newly privatized firms in developed and developing countries (e.g., Megginson, Nash and van Randenborgh, 1994; Boubakri and Cosset, 1998; D'Souza and Megginson, 1999; Dewenter and Malatesta, 2001). 9 Although these studies have shown that the outcomes of privatization tend to vary with the level of country development, none has examined the determinants of performance changes of newly privatized firms in developing countries. In this paper, we seek to provide an answer to the following question, namely when and how does privatization work? This question is timely because many developing countries only began to undertake large scale privatizations in the 1990s (Ramamurti, 1999). The results of this study should, therefore, be of interest to investors, government policy makers as well as officials of international agencies, such as the World Bank and the International Monetary Fund, by providing insights on the way privatization works.

This paper makes two main contributions. The first contribution is to assess the performance outcomes of privatization for a unique sample of newly privatized firms from a wide set of developing countries. Our analysis covers a large sample of 201 firms from 32 developing countries over the period 1980 to 1997. In doing so, we go beyond Boubakri and Cosset (1998) who consider a sample of 79 firms from 21 countries over the period (1980 to 1992). The data set we use represents the shift of privatization towards new industries (e.g., utilities and telecommunication) and new participating countries (such as African countries). Furthermore, this multi-national sample includes a large number of countries with different levels of economic and institutional development, at different stages of economic reforms and

\footnotetext{
${ }^{1}$ See Megginson and Netter (2001) and Djankov and Murrell (2001) for thorough reviews of the empirical literature on privatization.
} 
William Davidson Institute Working Paper 419

with a great variety of legal systems, providing us with a unique opportunity to assess the role of these country-wide factors in the performance of newly privatized firms.

The second contribution of the paper is to examine the determinants of performance changes of newly privatized firms by focusing on the specific environment of developing countries. We conjecture that, in order to explain how privatization works in such an environment, we need to account for (i) the ongoing economic reforms in developing countries, such as stock market and trade liberalization policies, as well as (ii) corporate governance, all of which could affect the outcome of privatization. The first set of factors is particularly important as it fundamentally distinguishes privatization in developing countries from that in developed countries since privatization in developing countries is generally implemented as part of a broader program of structural adjustment involving other concomitant economic reforms. For example, stock market and trade liberalizations could create stronger competition and higher growth rates likely to spur performance improvements. The second set of factors relates to the recent literature on the importance of a country's level of corporate governance and institutional development. Moreover, this constitutes a major difference between developed and developing countries, since the governance mechanisms are relatively weaker in the latter. Indeed, several authors recently emphasized the importance of a country's level of institutional development as a determinant of the failure or success of privatization programs (e.g., Ramamurti, 2000; Dyck, 2001; Shirley, 2001). Anecdotal evidence suggests that the modest gains of privatization in some developing countries are partly due to their lack of an institutional framework for efficient corporate governance. In this paper, we shall provide empirical support for these contentions and contribute to the existing literature by accounting for the features of developing countries in our assessment of the performance of newly privatized firms. In fact, this study unites in a single framework two streams of literature in development and financial economics: the first deals with the impact of economic reforms on 
William Davidson Institute Working Paper 419

the country- and firm-level performance (e.g., Dornbusch, 1992; Sachs and Warner, 1995; Bekaert and Harvey, 2000; Henry, 2000; Tybout, 2000; Bekaert, Harvey and Lundblad, 2001a,b); the second, the impact of corporate governance mechanisms, including the ownership structure and property rights, on the country- and firm-level performance (e.g., La Porta, López-deSilanes, Shleifer and Vishny, 1997, 1998, 1999, 2000; Demirgüc-Kunt and Maksimovic, 1998; Johnson, Boone, Breach and Friedman, 2000; Mitton, 2001).

Using a unique sample of 201 newly privatized firms, we first document a significant increase in both unadjusted and market-adjusted profitability, efficiency, investment and output. Next, partitioning our data into various subsamples, we show that the changes in operating performance vary with the extent of economic reforms and environment, and the effectiveness of corporate governance. For example, we demonstrate that privatization yields better results if it is preceded by trade and stock market liberalizations. Finally, performing a multivariate regression analysis, we find that economic reforms and environment as well as corporate governance variables explain post-privatization performance changes. In particular, we document that economic growth and stock market liberalization are associated with stronger profitability and efficiency gains and greater output increases. Moreover, our results suggest that trade openness and economic freedom are important determinants of the postprivatization increase in efficiency and output. Trade openness also appears to be associated with higher levels of post-privatization investment. In relation with corporate governance variables, we provide evidence that control relinquishment by the government is a key determinant of profitability and efficiency improvements as well as output increases following privatization. Furthermore, we find that foreign ownership is associated with stronger profitability gains. We likewise find that higher gains in efficiency and output occur for firms in countries with more developed stock markets and where property rights are better protected

\footnotetext{
2 A recent study by D'Souza, Megginson and Nash (2001) examines the determinants of performance changes for 119 firms from 29 countries including 18 firms from developing countries. However, the
} 
William Davidson Institute Working Paper 419

and enforced. These results are robust across various specifications. Taken together, our findings highlight the importance of corporate governance and economic reforms and environment in explaining the post-privatization changes in performance. Correspondingly, our findings have several policy implications for the different stakeholders involved in the privatization process.

The paper is organized as follows: the first section discusses the links between economic reforms, corporate governance and privatization. Section II describes the sample and data and outlines the methodology. Section III presents the results, while Section IV concludes and provides some policy implications.

\section{Economic Reforms, Corporate Governance and Privatization}

\section{A. Privatization and Economic Reforms}

Privatization in developing countries (DCs hereafter) is often accompanied by economic reforms such as stock market and trade liberalization that could influence the outcomes of a privatization program. Several authors have studied the effect of economic and financial reforms on the economies of DCs. For example, Henry (2000) examines the impact of stock market liberalization on the returns of twelve emerging stock markets. Controlling for macroeconomic fundamentals, co-movements with foreign stock markets and concurrent economic reforms (such as macroeconomic stabilization programs, trade liberalization, privatization and the easing of exchange controls), Henry finds a monthly mean abnormal return of 3.3 percent over an eight-month period leading up to the implementation of the stock market liberalization. The author also documents that privatization has a positive effect on stock returns. However, once he controls for the specific economic conditions of the country, the impact of privatization is no longer significant. Henry argues that one possible explanation

authors do not control for the specific environment of these countries in their study. 
William Davidson Institute Working Paper 419

for this result is that governments tend to privatize when the economic conditions are favorable. In related studies, Bekaert and Harvey (2000) and Bekaert, Harvey and Lundblad (2001a,b) analyze the impact of stock market liberalization in emerging markets on, among other things, the cost of equity capital (expected equity returns) and economic growth. Controlling for a number of other factors (such as the level of stock market development, the size of the trade sector and the macroeconomic environment) to isolate the sole impact of liberalization, they find that stock market liberalization is associated with lower costs of equity capital and higher economic growth rates. In light of these findings, we expect a positive association between privatization outcomes and stock market liberal ization.

Similarly, Dornbusch (1992) focuses on trade liberalization. He identifies several channels through which trade reforms could bring benefits. Examples include an improved allocation of resources, greater competition and an access to better technologies, inputs and intermediate goods. Thus, irrespective of privatization, trade liberalization could bring changes

in the performance of newly privatized firms (NPFs hereafter). Empirically, Henry (2000) shows that trade liberalization is associated with equity price revaluation, a result consistent with Sachs and Warner's (1995) evidence that this policy is closely tied to future growth.

The above evidence suggests that stock market and trade liberalization creates favorable economic conditions (e.g., stronger competition and higher growth rates) likely to spur performance improvements. Consequently, we need to account for the possible confounding effects of such economic reforms on the performance of newly privatized firms.

\section{B. Privatization and Corporate Governance}

Shleifer and Vishny (1997) and Dyck (2000), among others, argue that corporate governance can explain the performance of privatized firms. In developed countries, the governance system is 
William Davidson Institute Working Paper 419

relatively efficient in that investors are confident to obtain returns on their investments and firms can raise the necessary funds to finance their investment projects. In contrast, the governance mechanisms in DCs are generally weak and the risk of expropriation of shareholders by managers or by blockholders is considerable. This limits the financing opportunities for firms that need to invest or restructure, especially NPFs, since a direct consequence of privatization is usually a reduction (if not an elimination) of government subsidies. This, in turn, could affect post-privatization performance.

The literature generally distinguishes two types of corporate governance mechanisms, that is internal and external. Internal mechanisms include the ownership structure and the organizational structure of the firm, while external mechanisms include the monitoring of capital markets and the legal and institutional system.

Boycko, Shleifer and Vishny (1996) develop a model of privatization that explains the relative inefficiency of public firms and the improvements of post-privatization efficiency. Specifically, they present a model in which privatization transfers both control and cash flow rights to the managers who then place greater emphasis on profits and efficiency. Consequently, we expect the gains in performance to be higher when the government gives up control. In the same vein, the growing involvement of foreign investors could affect the postprivatization performance of NPFs. Foreign investors generally require high information discl osure standards, provide new funds to NPFs and, for reputation concerns, maintain a strict control of managers' actions (Dyck, 2000, Shirley, 2001). Therefore, we expect a positive association between post-privatization performance improvements and foreign ownership.

The other internal monitoring mechanisms that relate to the organizational structure of the firm are the Board of Directors (BOD hereafter) and Chief Executive Officer (CEO hereafter).

3 See Tybout (2000) for a comprehensive review of the evidence of the impact of trade liberalization on the performance of firms in developing countries. 
William Davidson Institute Working Paper 419

In the privatization literature, one reason often put forward to explain the poor performance of state-owned enterprises is the low qualification of government-appointed-BOD members and managers (López-de-Silanes, 1997). Furthermore, incentives to monitor managerial behavior are poor, leaving managers considerable discretion to pursue their personal agendas (Vickers and Yarrow, 1991; Shleifer and Vishny, 1997). Indeed, as noted by Özkaya and Askari (1999), old fashioned compensation schemes, based on tenure and not performance, prevail in the majority of DCs. Changes in the membership of the BOD as well as changes of the CEO can be put in place to ascertain more effective monitoring and management, respectively. The underqualified managers could be replaced by others whose objectives are more aligned with profit maximization, and new monitoring mechanisms could be put in place by the new shareholders. ${ }^{4}$ Therefore, we expect that restructuring the BOD and changing the CEO can affect the post-privatization performance.

As mentioned earlier, there also exist external mechanisms of corporate governance which include capital market monitoring and the legal system. The monitoring role of the market depends on the size and the sophistication of the local capital market (Subrahmanyam and Titman, 1999; Levine, 1997; Levine and Zervos, 1998). A large and sophisticated market implies (i) a "friendlier" market-and-regulatory environment, (ii) better access to the funds necessary to restructure the NPFs, and (iii) better monitoring and performance linkedcompensation for managers. Therefore, we expect the NPFs in relatively more sophisticated and larger stock markets to perform better.

Law and the quality of its enforcement are likely to influence the monitoring role played by the market. La Porta, López-de-Silanes, Shleifer and Vishny (1998) show that the legal protection of shareholder rights varies around the world. Specifically, countries with an

\footnotetext{
4 See, for example, Barberis, Boycko, Shleifer and Tsukanova (1996) who stress the importance of changing the human capital (directors and managers) as an incentive to maximize the privatized firm's value.
} 
William Davidson Institute Working Paper 419

English common law system offer stronger rights to shareholders and higher quality of law enforcement than do countries with a French civil law system do. In the same vein, Pagano and Roell (1998) argue that a market with a stronger protection of shareholder rights decreases the costs of agency and increases the efficiency of monitoring managers. Consequently, we expect post-privatization performance to be higher for countries where laws protect shareholder rights and which have a legal system that efficiently enforces these laws.

\section{Data and Methodology}

This section describes the sample of NPFs and outlines the methodology we use in our analysis.

\section{A. The Sample of Privatized Firms}

The initial sample of NPFs comes from Boubakri and Cosset (1998). It was updated with the World Bank list of firms privatized between 1990 and 1998. Our sample does not include privatized companies in the ex-communist countries since the process of privatization in this context is an intrinsic part of the transformation to a market-based system (Galal, Jones, Tandon and Vogelsang, 1994; Özkaya and Askari, 1999). Furthermore, the traditional law system in these countries is based on the Soviet law which underwent many changes during their transition period (La Porta, Lòpez-de-Silanes, Shleifer and Vishny, 2000).

To assess the post-privatization performance changes, we draw the financial information from the NPFs' financial statements, their web site, and from databases such as Worldscope

5 Other lists were provided by the local government agencies in charge of the privatization programs, such as the BNDES-Brazilian Development Bank for Brazil, the Ministry of Privatization for Morocco, the Tunisian Central Bank for Tunisia and the Privatization Administration for Turkey. By diversifying our data sources, we minimize the risk that only well-performing firms are included in the sample. 
William Davidson Institute Working Paper 419

Disclosure, Compustat (Global Vantage), M oody's International and Economatica. Using these different sources, we gather data for a sample of 201 firms headquartered in 32 countries. Table 1 provides some descriptive statistics on the 201 firms used in the study. The 201 firms are located in the following four geographical regions. Latin A merica and the Caribbean account for 33.33 percent of the firms, 24.38 percent come from Africa and the Middle East, 24.88 percent from East and South Asia and the Pacific and 17.41 percent from Europe and Central Asia. Interestingly, this diversification involves countries with different levels of development and different legal and institutional environments. Table 1 also shows that the sample is diversified across industries with 32.84 percent in the financial sector, 26.87 percent in the energy sector and 10.95 percent in utilities. Furthermore, 78 percent of the privatizations have occurred in the nineties, which reflects the recent trend towards large scale privatizations by DCs. Finally, the sample of NPFs covers three legal systems: 32.34 percent of the firms come from common law countries, 65.17 percent from French civil law countries and 2.49 percent from German civil law countries.

\section{B. Methodology}

In order to examine the impact of privatization on the operating performance of NPFs and to investigate the determinants of the changes in performance, we proceed with univariate and multivariate analyses. We first present the different partitions we analyze. Then, we describe the variables we include in the multivariate regression.

\section{B.1 Univariate Analysis}

We rely on four aspects of firm performance:

Profitability: We measure profitability by the return on sales (net income to sales), return on assets (net income to total assets) and return on equity (net income to equity) ratios. 
William Davidson Institute Working Paper 419

Efficiency: We measure operating efficiency by the sales efficiency (real sales per employee) and net income efficiency (net income per employee) ratios.

Investment: We measure investment by capital expenditures to sales and capital expenditures to total assets.

O utput: We measure output by real sales (nominal sales divided by the consumer price index).

The use of different performance measures allows us to draw up a more comprehensive assessment of the impact of privatization on the performance of the former state-owned enterprises. In particular, examining the first two groups of ratios reveals whether privatization helps to improve the profitability and the efficiency of the firm which are two of the main goals advanced by governments to advocate privatization.

We determine the performance measures presented above for a period of seven years (three years prior to privatization and three years post privatization, including the year of privatization itself). We then compute the means before and after privatization for each performance measure. We consider as the privatization date to be the date on which the government sold, for the first time, a certain amount of shares. We pay particular attention to the exact date of privatization by checking different sources of information, namely, the W orld Bank Privatization Database, Privatization International, the prospectuses and the answers to the questionnaires we sent to the candidate firms. To assess the significance of performance changes, we use the two-tailed Wilcoxon signed-rank test. We also use a proportion test that determines whether the proportion of firms with the anticipated changes is greater than 50 percent.

In order to investigate whether the changes in performance vary with the extent of economic reforms and environment and the effectiveness of corporate governance, we analyze the differences in performance between two groups of partitions. The first group includes partitions with respect to the extent of economic reforms and environment: 
William Davidson Institute Working Paper 419

(i) Firms privatized before trade (stock market) liberalization versus those privatized after trade (stock market) liberalization. We gather trade liberalization dates from Sachs and Warner (1995) and stock market liberalization dates from Bekaert, Harvey and Lundblad (2000a), and Henry (2000).

(ii) Firms privatized in countries with a high index of economic freedom (i.e., friendlier environment) and those privatized in countries with a lower index of economic freedom (more restrictive environment). The rationale underlying the use of this comprehensive index, constructed by Gwartney, Lawson and Samida (2000), is that countries with less economic freedom are characterized by a greater government intervention and a higher policy uncertainty, which may lead to economic inefficiency.

The second group of partitions analyzes the role of corporate governance in explaining the differences in the performance of NPFs:

(i) Revenue versus control privatization, that is, firms privatized by less than or equal to 50 percent versus firms privatized by more than 50 percent (Megginson, Nash and van Randenborgh, 1994).

(ii) Firms with foreign ownership versus firms with no foreign ownership.

(iii) Firms that change their CEO versus firms that do not change their CEO over the privatization window

6 This index, described below in Table 3a, is a range of objective components designed to identify how policies in key economic areas are consistent with economic freedom. This index ranges from 0 to 10 , with higher scores indicating higher levels of economic freedom.

7 We also contrast firms with a high-BOD-turnover versus firms with a low-BOD-turnover. Variables related to ownership structure, BOD and CEO are compiled from the prospectuses, the financial statements, and such publications as Worldscope D isclosure, M oody's International, A sian, Brazil and M exico Company $\mathrm{H}$ andbooks, and The Guide to A sian Companies. 
William Davidson Institute Working Paper 419

(iv) Firms in stronger legal and institutional environments versus firms privatized in weaker legal and institutional environments. We use a governance index by Gwartney, Lawson and Samida (2000) as a measure of the legal structure and security of property rights and the enforcement of contracts. Higher values of the index indicate more effective governance.

\section{B.2 Multivariate Analysis}

While the results of the univariate approach can offer some insight, they only document bivariate relationships and they do not control for the effect of other variables. Hence, we perform a multivariate analysis in which we regress the changes in performance indicators (i.e., profitability, efficiency, investment and output) on several potential explanatory variables, namely, economic reforms and environment and corporate governance variables. We also control for firm size and industry effects. Table 2 describes all the variables used in the regression analysis.

For each performance measure, we estimate different specifications of the following cross-sectional regression:

$$
\begin{array}{r}
\text { Performance Changes }=\alpha_{0}+\beta_{1}(\text { Economic Reforms and Environment Variables) } \\
\left.\left.+\beta_{2} \text { (Corporate Governance Variables }\right)+\beta_{3} \text { (Firm Size) }+\beta_{4} \text { (Industry Dummies }\right)+\varepsilon
\end{array}
$$

In addition to the variables described in sub-section B.1, we include such variables as the changes in the real GDP growth and the size of the trade sector (imports plus exports) divided by GDP. The use of real GDP growth allows us to control for the impact of economic growth on the post-privatization performance of NPFs. The size of the trade sector, motivated by Bekaert and Harvey (2000), is a proxy for an economy's openness to trade. As an alternative to the governance index, we use an indicator variable for NPFs operating in common law 
William Davidson Institute Working Paper 419

countries since these countries generally exhibit a higher protection of investors than do civil law countries (La Porta, López-de-Silanes, Shleifer and Vishny, 1998).

\section{Descriptive Statistics}

In Table 3a, we classify our sample of 32 countries according to the country's legal origin and present summary statistics on the macroeconomic variables (Panel A) and corporate governance variables (Panel B). With few exceptions, most of the stock market liberalizations occurred at the end of the eighties and during the nineties. Except for A rgentina, India and Pakistan, trade liberalization precedes stock market liberalization. Consistent with the observations of La Porta, López-de-Silanes, Shleifer, and Vishny $(1997,1998)$ for a smaller subsample of DCs, Panel B shows that countries with an English or German legal origin exhibit higher levels of stock market development and legal protections as well as a more favorable institutional environment than countries with a French civil law origin.

Figure 1 describes the mean level of the economic freedom index over the period 19801997 for the 32 countries classified into four geographical regions. The East and South Asian and the Pacific region exhibits the highest level of economic freedom (6.30), followed by Europe and Central Asia (6.03), Latin A merica and the Caribbean (5.77) and Africa and the Middle East (5.04). The relatively higher mean levels of economic freedom shown by the first two groups of countries reflect the fact that these countries implemented substantial economic reforms (trade and stock market liberalization) relatively earlier than the other groups. With the exception of Bangladesh, all countries from the East and South Asian and Pacific region and the European and Central Asian region implemented trade and/ or stock market liberalization by the end of the 1980s to early 1990s. Except for Trinidad and Tobago, Latin American and the Caribbean economies were liberalized by the early 1990s either through trade or stock market liberalization. The case of the African and Middle Eastern region is different since economic reforms started mainly in the early 1990s with the adoption of IMF-supported structural 
William Davidson Institute Working Paper 419

adjustment programs. Although considerable progress has been made in this region, many countries had not yet implemented trade liberalization (Côte D'Ivoire, Egypt, Senegal and Togo) and stock market liberalization (Côte D'Ivoire, Togo and Tunisia) by 1997. Thus, a recent IMF study developed an index of trade restrictiveness to facilitate cross-country comparisons and track the evolution of trade policy over time. Figure 2 reports the 1997 value of the index for the four regions. Countries from the African and the Middle Eastern region exhibit the highest scores suggesting that their trade regimes are the most restrictive ones. Tariffs - the most commonly used form of trade restrictiveness - were 20 percent higher in Africa than elsewhere in 1997.8 Figure 3 reports the average scores of the governance index, described in Panel B of Table 3, for the four geographical regions. The average scores over the period 198097 differ widely across regions. The European and Central Asian region exhibits the highest average score (7.02), followed by East and South Asia and the Pacific (6.34) and Latin America and the Caribbean (5.87). As in Figure 1, countries from A frica and the Middle East show the lowest average score (4.69). Figure 4 depicts the level of stock market development measured by the average turnover ratio over the period 1980-97. The average turnover ratio differs substantially across the four regions with countries from A frica and the Middle East displaying the lowest ratio. This observation is consistent with the basic prediction of the legal approach of corporate governance suggesting that the quality of laws and the effectiveness of their enforcement are key determinants of stock market development (see La Porta, López-de Silanes, Shleifer, and Vishny, 2000, and references therein).

Table $3 \mathrm{~b}$ presents some descriptive statistics on the post-privatization ownership structure and size (proxied by the natural logarithm of total dollar sales at the time of privatization) for the sample of NPFs. The mean (median) post-privatization government ownership is 32.49 (30) percent in English common law countries and 24.52 (5) percent in countries of other legal origins. Moreover, post-privatization government retained ownership

\footnotetext{
8 See “Trade: An Engine of Growth for A frica”, Finance \& D evelopment, December 1999.
} 
William Davidson Institute Working Paper 419

is higher in Asian countries than in African, Latin American and European countries. This is consistent with Ramamurti' s (1999) observation that the overwhelming pattern in Latin America has been to privatize control, not just ownership, while the more common pattern observed in East Asia was to privatize partially. Interestingly, the distribution of postprivatization government ownership by industry shows higher remaining stakes for strategic industries (utilities and telecommunication). As for the post-privatization foreign ownership, its mean (median) is 14.09 (6) percent for English common law countries and 18.29 (4.4) percent in other legal origin countries.

The descriptive statistics on the size of NPFs reveal some interesting patterns. Privatized firms from A frica and the Middle East are substantially smaller than those from the three other regions. The average (median) size of firms from this region is 10 (10.12), whereas it is 12.83 (12.99) for firms from the East and South Asian and Pacific region, 12.74 (12.95) for firms from Latin America and the Caribbean and 11.57 (12.28) for those from Europe and Central Asia. This observation is consistent with the fact that privatization programs in A frica and the Middle East mainly emphasized small and medium-sized firms. Additionally, privatization programs in this region did not involve strategic, large firms from utilities and telecommunication until very recently. As shown in Table 3, utilities and telecommunication firms are larger than firms from other industries. In industrialized countries, infrastructure was the leading sector in privatization, largely due to the divestiture of telecommunication in the United Kingdom, Japan and Germany. In DCs, most infrastructure privatizations took place in Latin America and the Caribbean. 
William Davidson Institute Working Paper 419

\section{Results}

In section A, we discuss the performance changes for our sample of 201 NPFs. We then discuss the univariate results for different partitions in section $\mathrm{B}$, and the regression results in section $\mathrm{C}$.

\section{A. Univariate Analysis for the Full Sample of NPFs}

\section{A.1 Raw Performance Measures}

Table 4 reports raw changes in the performance measures of our sample. All three profitability ratios, that is return on sales (ROS), return on assets (ROA) and return on equity (ROE) increase significantly after privatization. In discussing the results, we choose to focus on the first proxy (ROS) because it is less sensitive to inflation and accounting conventions than the two other profitability ratios. The mean (median) ROS increases significantly (at the 1 percent level) from $0.073(0.049)$ before privatization to $0.149(0.090)$ after privatization. An improvement in profitability is achieved by 61 percent of the sample firms. ROA and ROE also improve significantly at the 1 percent level. These results clearly show that NPFs in DCs significantly increase their profitability.

The two proxies for efficiency, namely sales efficiency (real sales per employee (SALEFF)) and net income efficiency (net income per employee (NIEFF)), show a significant improvement (at the 1 percent level) in both measures for 74 percent and 65 percent of the firms, respectively. For example, SALEFF increases from 0.967 (0.932) of year 0 before privatization to 1.319 (1.115) of year 0 after privatization. These results suggest that NPFs significantly improve their efficiency, an objective which governments launching privatization programs often invoke.

Both measures of investment, specifically, capital expenditures to sales (CESA) and capital expenditures to total assets (CETA), show a significant increase at the 1 percent level, for 72 percent and 68 percent of the firms, respectively. This result, combined with the above 
William Davidson Institute Working Paper 419

evidence on efficiency, suggests that NPFs increase their investment expenses and improve their efficiency in order to compete with their private counterparts (Megginson, Nash and van Randenborgh, 1994).

Table 4 also shows a significant increase (at the 1 percent level) in real sales (SAL). Output is increased by 72 percent of the firms, from 1.147 (0.939) before privatization to 1.294 (1.128) after privatization. This result goes against the often advanced argument that SOEs tend to overproduce to satisfy political objectives (Boycko, Shleifer and Vishny, 1996). One possible explanation for the increase in output lies in the availability of better incentives and more flexible financing opportunities following privatization (Megginson, $\mathrm{N}$ ash and van Randenborgh, 1994). Furthermore, Table 3 shows an insignificant decrease of 116 employees on average after privatization. This result is consistent with that of D'Souza and Megginson (1999) who find an insignificant decline in employment for a sample of firms privatized during the 1990s. This is in contrast to the results of La Porta and Lòpez-de-Silanes (1999) who find a significant decline in the number of employees for their sample of Mexican NPFs.

Overall, the experience of our sample shows that privatization led to a significant increase in the operating performance of NPFs, as measured by profitability, efficiency, output and investment.

\section{A.2 Market-Adjusted Performance Measures: Does Privatization Work?}

A difficulty in isolating the impact of privatization on the performance of firms, particularly in DCs, lies in the fact that the observed changes may be due to contemporaneous economy-wide factors such as ongoing economic reforms. Consequently, to check the robustness of our previous unadjusted results, we perform tests with market-adjusted performance measures.

Using a large control sample of non-privatized firms, we compute market-adjusted performance measures as the difference between the median market performance and the firm's 
William Davidson Institute Working Paper 419

performance, for a given performance indicator. However, as firms from the financial and real sectors exhibit different operating and financial profiles, we use a financial-market index to compute market-adjusted performance measures for banks and insurance companies. For other firms, the market index consists of non-financial corporations. Table 5 presents, for the sample of firms for which we could compute market-adjusted performance measures, both unadjusted and adjusted results. In the years preceding privatization, the SOEs underperform the market since the average market-adjusted profitability and efficiency ratios are negative. This result suggests that privatized firms are profitable (according to their raw performance before privatization) but that these firms still underperform compared to their private counterparts. Additionally, the results reveal that privatization yields significant improvements in the adjusted performance measures. The unadjusted and adjusted profitability, efficiency and output ratios show a significant improvement (at the 1 percent level). As for investment, the unadjusted and adjusted ratios show a significant increase at the 5 percent and 10 percent, respectively. Nevertheless, according to the proportion tests, the percentage of firms that behaved as predicted is larger when we use unadjusted performance measures for the efficiency, investment and output suggesting that some of the performance changes for NPFs could be due to changes in economic conditions. To summarize, even after controlling for contemporaneous economy-wide factors, privatization still yields performance improvements. The next section examines whether privatization yields the same results in all regions.

\section{A.3 Cross-Regional Analysis of Performance Changes}

The descriptive statistics presented in sub-section II-C suggest that variables related to economic reforms and conditions and to corporate governance differ widely across the four geographic regions in our sample. If the changes in performance of NPFs vary with the extent of economic reforms and corporate governance mechanisms, then one would expect the privatization outcome to differ across regions with different stages of economic and institutional development. 
William Davidson Institute Working Paper 419

Table 6 reports the changes in performance for the sample of 201 privatized firms classified within four geographical regions. The multi-sample nonparametric Savage test rejects (at the 5 percent level) the null hypothesis that there is no difference in the profitability (ROS), efficiency (SALEFF) and output (SAL) changes across the four regions. Post-privatization improvements in profitability are significant for East and South Asia and the Pacific and for Latin America and the Caribbean. Except for Africa and the Middle East, the regions exhibit significant increases in efficiency and output. As discussed above (sub-section II-C), the limited level of economic freedom, the lack of developed stock markets and the low quality of laws and their enforcement in the countries of this region could explain why profitability, efficiency and output do not improve much for Africa and the Middle East. Finally, post-privatization changes in investment are significant at the 1 percent level for the African and Middle Eastern region, at the 5 percent level for the Latin A merican and Caribbean region and at the 10 percent level for the East and South Asian and Pacific region. The importance of foreign investors involved in the privatization process in Africa and Latin America ( an average of 19.86 and 26.12 percent, respectively), as compared to other regions (an average of 9.95 and 7.20 percent), could explain these results. Indeed, foreign investors are generally perceived as a source of capital and managerial know-how. Similarly, government ownership after privatization is much lower in Africa and Latin America (an average of 21.14 and 13.27 percent, respectively) where control privatizations dominate, thus providing new owners with the necessary incentives to restructure and invest.

Overall, the results from Table 6 show that performance gains from privatization vary widely across regions. This further motivates the need to explore the determinants of postprivatization performance changes, particularly those related to economic reforms and conditions and corporate governance variables. 
William Davidson Institute Working Paper 419

\section{B. Univariate Analysis of Different Subsamples}

In this sub-section, we discuss the results obtained for the partitions discussed in sub-section IIB. Panel A of Table 7 compares the changes in performance for firms privatized before and after trade liberalization. The gains in profitability, efficiency and output are significantly more important for firms privatized after trade liberalization. For example, the mean (median) improvement in profitability is 9.2 (3.9) percent for firms privatized after trade liberalization versus $3.5(0.9)$ percent for firms privatized before trade liberalization. The differences are significant at the 5 percent level for profitability, efficiency and output. Consequently, our results suggest that the implementation of trade liberalization prior to privatization is associated with higher improvements in the performance of NPFs. This result is consistent with Dornbusch's (1992) argument that trade liberalization allows a better resource allocation in the firm and the economy, an easier access to up-to-date technology and inputs, and increased competition!

Panel B of Table 7 presents the results for stock market liberalization and shows that there are significant differences (at the one percent level) between the performance changes of firms privatized before and those privatized after such a liberalization, particularly for efficiency and output. Therefore, these results confirm those in Panel A, relative to trade liberalization. We also consider a partition based on the degree of economic freedom that

9 To further check the robustness of the trade effect on performance changes, we use the trade restrictiveness index developed by the International Monetary Fund. Given that the index is available only from 1997 and that our sample period extends from 1980 to 1997, we need to conduct several experiments using this index. First, we limit the analysis to firms (17) privatized in 1997 and we contrast the changes in performance of those firms from countries with a relatively high level of trade restrictiveness versus those from countries with relatively low level of trade restrictiveness. The results, not reported here but available from the authors upon request, tend to corroborate those presented in Table 7. Second, since it is unlikely that the index varies significantly over a period of five years, we include firms privatized in 1995 and 1996 in the sample (40). The results remain qualitatively similar.

10 We also examine the combined effects of trade and stock market liberalizations on the performance of NPFs. Accordingly, we contrast the performance changes for firms privatized before trade and stock 
William Davidson Institute Working Paper 419

proxies for the extent of government intervention and policy uncertainty in a country. Panel C shows that the gains in efficiency and output are significantly higher (at the 5 and 1 percent levels, respectively) for firms privatized in a country with a higher degree of economic freedom. This result supports the claim that government intervention reduces privately owned firms' incentives to restructure and to improve performance.

Table 8 examines the impact of corporate governance mechanisms on the performance changes of NPFs. In Panel A of Table 8, we contrast the performance changes for firms where the government relinquishes control (control privatizations) versus those where it remains a majority shareholder (revenue privatizations). The results show that control privatizations realize higher gains in profitability, efficiency and output than revenue privatizations. This evidence is consistent with Boycko, Shleifer and Vishny 's (1996) prediction that the lower the government's shareholdings, the more likely it is that restructuring will occur and performance will improve.

As discussed earlier, the involvement of foreign investors in NPFs brings monitoring and expertise to the firms, which can have an impact on their operating performance. Hence, we compare firms with foreign ownership after privatization and firms with no foreign ownership after privatization! The results reported in Panel B show that the gains in profitability, efficiency and output are more important for the first sub-sample. For example, firms with foreign investors achieve an average (median) improvement of 13.1 (8.2) percent in profitability, 54 (27.7) percent in efficiency and 14.9 (2.7) percent in investment, as well as 44.1 (23.8) percent in output. For those firms with no foreign ownership, the gains in efficiency and

market liberalization versus those privatized after these two reforms. The results, though not reported here, tend to support the previous findings and show significant differences (at the 1 percent level) between the two sub-samples for efficiency and output. 
William Davidson Institute Working Paper 419

output are less significant. Their profitability increases insignificantly. The difference between both sub-samples is significant at the 1 percent level only for ROS. Taken together, these results confirm that the role of the ownership structure (private and foreign) is non negligible in providing corporate governance functions, especially when legal protections are weak (Dyck, 2000).

As previously discussed in section II-C, we consider a partition based on CEO turnover. Panel $\mathrm{C}$ shows that the performance changes for NPFs with a change in CEO are higher than those of firms with no CEO turnover. The CEO turnover sub-sample achieves an improvement of 8.4 (6.3) percent in profitability compared to 4.2 (1.7) percent for the no-CEO turnover subsample. The difference between both sub-samples is significant at the 5 percent level. The results also indicate a higher increase in efficiency for NPFs with a new appointed CEO after privatization. The Kruskal-Wallis test shows that the difference between sub-samples is marginally significant (at the 10 percent level). Hence, our evidence provides some support for the argument that the CEO turnover, with a new team of managers, increases the probability that a restructuring occurs in the firm that leads to a better performance (Barberis, Boycko, Shleifer and Tsukanova, 1996).

In Panel D, we contrast the performance of NPFs in countries with less effective governance and those with more effective governance. We find higher changes in efficiency and output for NPFs in countries with stronger legal protections and better institutional

11 To assess the impact of foreign ownership on post-privatization performance, we exclude firms with foreign ownership prior to privatization.

12 A survey conducted by La Porta and Lòpez-de-Silanes (1999) also provides evidence that the introduction of new production processes and the firing of the old management are the two most important success factors contributing to the postprivatization improvements in the operating efficiency of NPFs in Mexico. 
William Davidson Institute Working Paper 419

environment. The Kruskal-Wallis test indicates that the difference between both sub-samples is significant at the 1 percent level. These results suggest that the legal and institutional environment affects the performance of NPFs in DCs. ${ }^{14}$ This evidence confirms Ramamurti's (2000) and Dyck's (2001) claim that the level of a country's institutional development should contribute to the success of its privatization programs.

The results presented in the univariate analysis provide some insight on the role of economic reforms and conditions as well as corporate governance variables. However, multivariate regressions can be more insightful because they take into consideration the role of these variables jointly.

\section{Multivariate Regression Analysis}

In Table 9, we report the results of a multivariate regression analysis in which the changes in profitability, efficiency, investment and output are regressed on three groups of independent variables, namely the economic reforms and environment variables, the corporate governance variables, and the firm and industry characteristics. All four models are estimated independently with three different specifications each. These specifications allow us to

13 We also examine performance changes for NPFs with high-BOD-turnover versus those with low-BODturnover. The results (not reported here but available upon request) from the Wilcoxon test indicate a significant increase in profitability, sales efficiency and output for both subsamples.

14 Since the degree of stock market development is directly related to the legal and institutional environments (La Porta, López-de-Silanes, Shleifer, and Vishny, 1998, 2000), we contrast, as an alternative partition, firms privatized in low-turnover stock markets versus firms privatized in high-turnover stock markets. We employ the ratio of total value of shares traded divided by the average market capitalization (turnover ratio) as measures of the liquidity of the local stock market. The results suggest important gains in performance for high-turnover markets. The difference in performance between both groups is highly significant (at the 1 percent level) for efficiency and output. This evidence is consistent with the argument that the levels of market development and sophistication play a crucial role in the success of privatization programs in DCs. The results, based on an alternative measure of stock market development, namely the ratio of market capitalization (total market capitalization/ GDP), are qualitatively similar. 
William Davidson Institute Working Paper 419

separately include variables that are highly correlated (for example, legal protection and stock market development). Furthermore, since privatization programs could affect some institutional and stock market development indicators (Boutchkova and Megginson, 2000), thus creating a certain endogeneity, we introduce the lagged (pre-privatization) values of these indictors in our regressions.

\section{C.1 Profitability}

Panel A of Table 9 reports the results for the profitability model. In all three specifications, we observe a significant (at the 1 percent level) positive relationship between the change in profitability and the change in GDP growth over the privatization window. Consistent with Bekaert and Harvey (2000) and Henry (2000), specification (i) indicates a positive and statistically significant relationship between the change in profitability and stock market liberalization. In relation to corporate governance variables, we document a significant positive relationship between profitability changes and control relinquishment by the government. This result is consistent with Boycko, Shleifer and Vishny (1996) and Shleifer and Vishny (1997) who conclude that privatization typically transfers the control from politicians to private owners who then show greater interest in profits and efficiency. Furthermore, specifications (ii) and (iii) indicate that firms with foreign investors achieve higher profitability gains by 6.3 percent. This result supports Dyck's (2000) and Shirley's (1999) arguments that foreign ownership can improve privatization outcomes in DCs where legal protections are weak. Moreover, small NPFs show higher profitability changes following privatization, suggesting that relatively smaller SOEs adapt more easily to a change in the environment. Finally, we find that profitability improvement is significantly higher for noncompetitive firms (utilities and telecommunication). In sum, the results indicate that variables related to the economic reforms and environment, the ownership structure, and the legal protection explain at least 23 percent of the variation in profitability changes. 
William Davidson Institute Working Paper 419

\section{C.2 Sales Efficiency}

Panel B reports the results for the efficiency model. Consistent with the results reported in Table 7, specifications (i) and (iii) indicate a significant positive relationship (at the 1 percent level) between changes in sales efficiency and stock market and trade liberalization, respectively. The positive effect of trade openness is consistent with Dornbusch's (1992) argument that trade liberalization leads to a higher competition and a better allocation of resources. Interestingly, specification (ii) reports a positive and statistically significant relation between changes in sales efficiency and the level of economic freedom before privatization. This evidence suggests that the extent of government intervention in the economy affects the NPFs' efficiency. We also observe a significant (at the 10 percent level) positive relationship between the change in sales efficiency and the change in GDP growth during the privatization window (specification (ii)). The positive effect of GDP growth is no longer significant when we control for the stock market liberalization and the changes in trade openness (specifications (i) and (iii)). This result is consistent with those of Bekaert and Harvey (2000) and Bekaert, Harvey and Lundblad $(2001 a, b)$ who find evidence that stock market liberalization and trade openness are associated with higher economic growth.

Regarding the corporate governance variables, all three specifications show a significant positive relationship between changes in efficiency and control relinquishment by the government. This result is consistent with the often-invoked argument that government's control is the source of inefficiency at the firm-level (Kikeri, Nellis and Shirley, 1992; Boycko, Shleifer and Vishny, 1996). Interestingly, consistent with D'Souza, Megginson and Nash (2001), our results show a significant positive relationship between sales efficiency changes and capital market development (i.e, the turnover ratio). This result confirms the claim that active capital markets influence the firms' performance through its monitoring role. Several authors argue that legal protections and institutional development have a positive impact on stock market development (La Porta, López-de-Silanes, Shleifer and Vishny, 1997, 2000). Therefore, we rerun 
William Davidson Institute Working Paper 419

the tests using a governance index as a proxy for the legal protections and their enforcement by institutions (specification (iii)). Not surprisingly, the results indicate a significant positive relationship at the 1 percent level between sales efficiency changes and this proxy. This could explain why privatization failed to improve NPFs' performance in our sample of African and Middle East countries where weak legal protections and inefficient institutions prevail (see Table 3a and Figure 3). An implication of this evidence is that legal and institutional reforms should be encouraged in these countries before launching a privatization program.

Our specifications explain between 15 and 28 percent of the changes in sales efficiency after privatization. Overall, our data indicate that economic reforms and the extent of economic freedom, government control relinquishment and the level of institutional/stock market development are key determinants of post-privatization efficiency improvements.

\section{C.3 Investment}

In Panel C, we present the estimated regression coefficients for the investment model. Unlike the profitability and efficiency models, the results for the investment model are surprising, as few variables help to explain the changes in capital expenditures. Across the three specifications, only specification (iii) shows a significant positive relationship between changes in capital investment expenditures and changes in trade openness, suggesting that trade liberalization can foster the investment at the firm level. This result is consistent with Dornbusch's (1992) argument that trade liberalization increases domestic competition and thus the incentives for firms to improve their productivity to survive in a highly competitive environment. Undoubtedly, this should be achieved through investment. The regression results are also consistent with the univariate findings reported in Tables 7 and 8 where economic reforms and environment and corporate governance variables did not provide any insights into the determinants of post-privatization investment changes. These results are not surprising since NPFs from the African and Middle Eastern region, where economic reforms had not been fully implemented and where weak legal and institutional environments prevail, 
William Davidson Institute Working Paper 419

actually achieved significant improvements in investment (see Table 6). D'Souza, Megginson and Nash (2001) also find no significant variables in their investment model, except for employment.

\section{C.4 Output}

Panel $D$ reports the results for the output model. Consistent with the univariate analysis, the results of the regression analysis show that economic reforms and environment as well as corporate governance variables are important determinants of output changes. Specifications (i) and (iii) indicate a positive association between output changes and stock market liberalization and trade openness, respectively. This evidence suggests that firms become more productive in the presence of economic reforms. Specification (ii) shows that the index of economic freedom before privatization is a positive and significant determinant of output changes. This result is

consistent with the prediction that, the lower the intervention of the government in the economy and thus the friendlier the environment, the higher the willingness to increase production. In specification (ii), the change in economic growth appears to be positively and significantly related to output changes after privatization. However, as discussed for the efficiency model, once we control for stock market liberalization and trade openness the variable is no longer significant.

Regarding the corporate governance variables, the regression analysis shows a significant positive relationship between output changes after privatization and control relinquishment by the government. Whatever the specification, this result is robust and the magnitude of the coefficient associated with the control dummy variable remains stable. These results, combined with those discussed with the independent variable index of economic freedom, suggest that post-privatization output increases are larger with lower government intervention at the firm-level and the country-level. Interestingly, stock market development, as measured by the turnover ratio, has a significant positive impact on output changes suggesting that firms divested in countries with more developed stock markets become more productive. 
William Davidson Institute Working Paper 419

This result supports the claim that more devel oped stock markets are more efficient monitors. Finally, specification (iii) indicates a positive and statistically significant relation between output changes and the level of legal and institutional development. This evidence suggests that NPFs in environments where property rights are better protected and enforced become more productive.

In short, the results indicate that economic reforms and environment and corporate governance variables are key determinants of output changes following privatization. These variables explain between 7 and 17 percent of the variation in output after divestiture.

\section{Robustness Checks and Econometric Issues}

In this section, we assess the robustness of our results by running a series of experiments.

\section{Cross-sectional correlation}

In order to examine the sources of post-privatization performance changes, we estimated the equations for the respective change in profitability, efficiency, investment and output independently. However, we cannot rule out the possibility that there might be a contemporaneous correlation between the error terms. For example, a contemporaneous correlation might arise because (1) we are estimating the change in each performance measure over the same time period and (2) the firms in the sample might exhibit certain common characteristics. One way to tackle this problem is to estimate the performance equations in a joint regression, i.e., in a seemingly unrelated regressions (SU R) system. Although the number of observations decreases markedly for this joint estimation, the unreported results remain qualitatively similar to those obtained from an OLS on the same subsample and the full sample (see Table 9). 
William Davidson Institute Working Paper 419

Selection Bias

One concern in our analysis is related to a potential selection bias stemming from the possibility that governments (1) sell firms to insiders, or (2) privatize those firms that are more likely to achieve performance improvements. The first situation occurs when insider owners who are about to acquire the firm have an incentive to depress the pre-privatization performance, which could affect the extent of improvements after divestiture. In contrast to post-communist countries, insider privatizations are very rare in DCs. However, we identify the three insider privatizations in our sample and exclude them from the analyses. Unsurprisingly, the results do not change.

The second situation stems from the possibility that governments do not randomly sel ect the firms to be privatized, but rather begin by putting up "better" firms (i.e, those that are more likely to achieve performance improvements) for sale first. In such a case, the inferences from our multivariate analysis might change because certain determinants could be related to the timing of privatization. To tackle this problem, we construct an early variable that takes the value of one if the firm is privatized before the median privatization date in the country, and zero otherwise. We then reestimate the specifications reported in Table 9 but the magnitude and significance of the coefficients remain unchanged. Moreover, the variable early is insignificant in 11 out of 12 specifications. Overall, our findings on the performance effects of privatization and their determinants do not seem to be driven by a sel ection bias.

\section{O utliers}

The presence of outliers could affect our univariate and multivariate results. To address this concern, we conduct the same tests using a censored (reduced) sample of NPFs that eliminates the impact of outliers. Although not reported here, the univariate and multivariate results are

15 For each performance measure, the reduced sample is obtained by eliminating observations that are more than three standard deviations away from the performance mean value. This procedure yields 178 observations for ROS, 181 for ROA, 180 for ROE, 116 for SALEFF, 112 for NIEFF, 134 for CESA, 135 for 
William Davidson Institute Working Paper 419

qualitatively similar to those reported in Tables 4 through 8 and in Table 9, respectively. This would suggest that our inferences are not driven by outliers. We also use regression techniques that are robust to outliers and we find that our results remain the same, suggesting that outliers do not drive our regression results.16

\section{Summary and Policy Implications}

This is the first multi-national study to investigate the determinants of performance changes for newly privatized firms in the specific context of developing countries. First, using a large and diversified sample of 201 firms, we document a significant increase in both unadjusted and market-adjusted profitability, efficiency, investment and output. These results highlight the superiority of private ownership compared to state ownership and are consistent with the agency theory which suggests that privatization helps to mitigate agency problems that arise from the separation of ownership and control in the formerly state-owned enterprises. Next, using univariate comparisons and nonparametric tests, we show that changes in performance vary with the extent of economic liberalization and corporate governance mechanisms. More specifically, we show that privatization yields better results when trade and stock market liberalizations precede it. This result provides a tentative explanation for the failure of privatization programs to improve the performance of privatized firms in some developing countries, particularly those that privatized in a protected environment.

Our multivariate analysis allows us to shed further light on the most important determinants of performance changes after privatization Consistent with our predictions,

CETA and 180 for SAL. Summary descriptive statistics for the censored sample are available from the authors upon request.

16 We use the Least Median of Squares (LMS) and Least Trimmed Squares (LTS) subroutines developed by Rousseeuw and Leroy (1987). 
William Davidson Institute Working Paper 419

economic reforms and conditions as well as corporate governance variables appear to drive the performance improvements of newly-privatized firms in developing countries. In brief, our results show that control relinquishment by the government and the extent of foreign ownership are important determinants of performance changes. Legal protection and the extent of government intervention in the economy (as proxied by the Economic Freedom Index), are also positively related to performance improvements. Finally, trade and stock market liberalization as well as the level of economic freedom have a positive impact on investment improvements suggesting that economic reforms create favorable conditions and the necessary incentives for NPFs to make the investments they need to improve their efficiency and profitability. The success of privatization is further enhanced by an adequate institutional environment that insures the protection of property rights and law enforcement. In countries where legal protection is weak, performance gains can only be modest as illustrated by the privatization experience of African countries.

As academicians and policy makers have recently suggested, there is a need to reform the legal systems in developing countries and make them stronger and more efficient in order to reduce the contractual uncertainty in transactions between firms and improve incentives for both domestic and foreign firms to invest. Foreign investors, in particular, appear to be instrumental in stimulating the positive change in the performance of newly privatized firms.

Hence, attempts to privatize in the absence of an effective institutional framework are likely to fail as witnessed by the experience of African countries. The experience of our sample shows that, in order to ensure positive privatization outcomes, stock market and trade liberalizations should take place before privatization is implemented. Indeed, trade liberalization will lead to greater competition and a better allocation of resources while stock market liberalization will bring technological innovation and progress as well as new physical and human capital through the involvement of foreign investors. All these economic changes will create an environment that provides firms with the necessary incentives to invest and 
William Davidson Institute Working Paper 419

restructure in order to face the competition of their private peers. What is more, when privatization follows liberalization (and other significant changes in the economic setting), it reduces the risk of reversibility of the privatization policy.

In summary, the main policy implications of our results are as follows. First, governments should implement economic reforms (trade and stock market liberalization) before privatization. Liberalization creates a favorable environment for business and helps to attract foreign investors who are major providers of new funds and technology to the privatized firms. Second, although external corporate governance mechanisms are still weak in developing countries (namely, markets for corporate control and for managers), stock market development contributes by addressing agency problems and improves resource allocation. For the market to play an active role in better resource allocation, governments in developing countries should ensure a better legal protection for minority shareholders and improve the institutional setting to attract foreign investors. Our results add to the growing empirical evidence that supports the role of the legal protection of investors and enforcement by institutions in explaining cross-country and cross-firm differences in performance. 


\section{References}

Barberis, Nicholas, Maxim Boycko, Andrei Shleifer and Natalia Tsukanova, 1996, "How Does Privatization Work? Evidence from Russian Shops", J ournal of Political Economy 104, 764-790.

Bekaert, Geert and Campbell Harvey, 2000, “Foreign Speculators and Emerging Equity Markets", Journal of Finance 55, 565-613.

Bekaert, Geert, Campbell Harvey and Christian Lundblad, 2001a, "Emerging Equity Markets and Economic Development", J ournal of D evelopment E conomics 66, 465-504.

Bekaert, Geert, Campbell Harvey and Christian Lundblad, 2001b, “Does Financial Liberalization Spur Growth?", Working Paper 8245, National Bureau of Economic Research.

Boubakri, Narjess and Jean-Claude Cosset, 1998, “The Financial and Operating Performance of Newly Privatized Firms: Evidence from Developing Countries", Journal of Finance 53, 1081-1110.

Boutchkova, Maria K. and William L. Megginson, 2000, “ Privatization and the Rise of Global Capital Markets", Financial M anagement 29, 31-76.

Boycko, Maxim, Andrei Shleifer, and Robert Vishny, 1996, "A Theory of Privatization", The Economic Journal 106, 309-319.

Demirgüc-Kunt Asli and Vojislav Maksimovic, 1998, "Law, Finance, and Firm Growth", Journal of Finance 53, 2107-2139.

Dewenter, Kathryn and Paul H. Malatesta, 2001, "State-Owned and Privately-Owned Firms: An Empirical Analysis of Profitability, Leverage, and Labour Intensity", A merican Economic Review 91, 320-334.

Djankov, Simeon and Bernard Hoekman, 2000, "Market Discipline and Corporate Efficiency: Evidence from Bulgaria", Canadian Journal of Economics 33, 190-212.

Dornbusch, Rudiger, 1992, “The Case of Trade Liberalization in Developing Countries", Journal of Economic Perspectives 6, 69-85.

Dow, James and Gary Gorton, 1997, "Stock Market Efficiency and Economic Efficiency: Is There a Connection?", J ournal of Finance 52, 1087-1129.

D'Souza, Juliet and William Megginson, 1999, “The Financial and Operating Performance of Privatized Firms during the 1990s", Journal of Finance 54, 1397-1438.

D'Souza, Juliet and William Megginson and Robert Nash, 2001, “Determinants of Performance Improvements in Privatized Firms: The Role of Restructuring and Corporate Governance", W orking Paper, University of Oklahoma.

Dyck, Alexander I. J., 2000, "Ownership Structure, Legal Protections and Corporate Governance", W orking Paper, Harvard Business School. 
William Davidson Institute Working Paper 419

Dyck, Alexander I. J., 2001, “Privatization and Corporate Governance: Principles, Evidence and Future Challenges", The World Bank Research O bserver 16 (Spring), 59-84.

Galal, A hmed, Leroy Jones, Pankaj Tandon and Ingo Vogelsang, 1994, “Welfare Consequences of Selling Public Enterprises", W orld Bank, Washington, DC.

Gwartney, James, Robert Lawson and Dexter Samida, 2000, “Economic Freedom of the World: Annual Report," The Fraser Institute.

Henry, Peter Blair, 2000, “Stock Market Liberalization, Economic Reform, and Emerging Market Equity Prices" J ournal of Finance 55, 529-564.

Johnson, Simon, Peter Boone, Alasdair Breach and Eric Freedman, 2000, "Corporate Governance in the Asian Financial Crisis", J ournal of Financial Economics 58, 141-186.

La Porta, Rafael and Florencio López-de-Silanes, 1999, “The Benefits of Privation: Evidence from Mexico", The Q uarterly J ournal of Economics 114, 1193-1242.

La Porta, Rafael, Florencio López-de-Silanes, Andrei Shleifer, and Robert W. Vishny, 1997, “Legal Determinants of External Finance", J ournal of Finance 52, 1131-1150.

La Porta, Rafael, Florencio López-de-Silanes, Andrei Shleifer and Robert W. Vishny, 1998, “Law and Finance", Journal of Political E conomy 106, 1113-1150.

La Porta, Rafael, Florencio López-de-Silanes, Andrei Shleifer, and Robert W. Vishny, 1999, "Investor Protection and Corporate Valuation", NBER Working Paper 7403, National Bureau of Economic Research, Cambridge, MA.

La Porta, Rafael, Florencio López-de-Silanes and Andrei Shleifer, 2000, “Investor Protection and Corporate Governance", J ournal of Financial Economics 58, 3-27.

Levine, Ross, 1997, “Financial Development and Economic Growth: Views and Agenda”, Journal of Economic Literature 35, 688-726.

Levine, Ross and Sara Zervos, 1998, “Capital Control Liberalization and Stock Market Development", W orld D evelopment 26, 1169-1183.

López-de-Silanes, Florencio, 1997, “Determinants of Privatization Prices”, The Q uarterly Journal of Economics 112, 965-1025.

Megginson, William and Jeffry M. Netter, 2001, “ From State to Market: A Survey of Empirical Studies on Privatization", J ournal of E conomic Literature 34, 321-389.

Megginson, William, Robert Nash, and Matthias Van Randenborgh, 1994, "The Financial and Operating Performance of Newly Privatized Firms: An International Empirical Analysis", Journal of Finance 49, 403-452.

Mitton, Todd V., 2001, "A Cross-Firm A nalysis of the Impact of Corporate Governance on the East Asian Financial Crisis", Journal of Financial Economics, forthcoming. 
William Davidson Institute Working Paper 419

Özkaya Mehmet and Hossein Askari, 1999,"Management of Newly Privatized Companies: Its Importance and How Little We Know", W orld D evelopment 27, 1097-1114.

Pagano, Marco and Ailsa Roell, 1998, "The Choice of Stock Ownership Structure: Agency Costs, Monitoring, and the Decision to Go Public", The Q uarterly Journal of Economics 113, 187-225.

Rajan, Raghuram and Luigi Zingales, 1998, "Financial Dependence and Growth", A merican Economic Review 88, 559-586.

Ramamurti, Ravi, 1991, "The Search for Remedies", In Privatization and Control of State-0 wned Enterprises, R. Ramamurti and R. Vernon, EDI Development Studies, The World Bank, Washington, D.C.

Ramamurti, Ravi, 1999, “Why Haven't Developing Countries Privatized Deeper and Faster?", W orld D evelopment 27, 137-155.

Ramamurti, Ravi, 2000, "A Multivariate Model of Privatization in Emerging Economies", A cademy of M anagement Review 25, 525-550.

Rousseeuw, Peter and A. M. Leroy, 1987, R obust Regression and O utlier D etection, Wiley Series In Probability and Mathematical Statistics, John Wiley, N ew York.

Sachs, Jeffrey D. and Andrew M. Warner, 1995, “ Economic Reform and the Process of Global Integration", Brookings Papers on Economic A ctivity, 1-113.

Shirley, Mary, 1999, "Bureaucrats in Business: The Roles of Privatizations versus Corporatization in State-Owned Enterprise Reform", W orld D evelopment 27, 115-136.

Shirley, Mary, 2001, “Experience with Privatization: A New Institutional Economics Perspective", J ournal of A frican Economies, forthcoming.

Shleifer, Andrei and Robert W. Vishny, 1997, "A Survey of Corporate Governance", Journal of Finance 52, 737-777.

Stulz, René, 2000, "Globalization of Equity Markets and the Cost of Capital," Journal of Applied Corporate Finance, forthcoming.

Subrahmanyam, Avanidhar and Sheridan Titman, 1999, “ The Going Public Decision and The Development of Financial Markets ", Journal of Finance 54, 1045-1082.

Tybout, James R., "Manufacturing Firms in Developing Countries: How Well Do They Do and Why?", Journal of Economic Literature 38, 11-44.

Vickers, John and George Yarrow, 1991, “Economic Perspectives on Privatization”, Journal of Economic Perspectives 5, 111-132.

White, Halbert, 1980, “A Heteroskedasticity-Consistent Covariance Matrix Estimator and a Direct Test for Heteroskedasticity", Econometrica 48, 111-132. 


\section{Description of the Sample of N ewly Privatized Firms in D eveloping Countries}

This table provides some descriptive statistics for the sample of the 201 privatized firms used in this study. We report the distribution of privatizations in the countries included in the sample by year, industry, legal origin and region.

\begin{tabular}{|c|c|c|c|c|c|}
\hline \multicolumn{6}{|c|}{ Distribution of Privatizations } \\
\hline \multicolumn{3}{|c|}{ By Year } & \multicolumn{3}{|c|}{ By Industry } \\
\hline Year & Number & Percentage & Industry & Number & Percentage \\
\hline 1980 & 1 & 0.50 & Financial & 66 & 32.84 \\
\hline 1981 & 1 & 0.50 & Utilities & 22 & 10.95 \\
\hline 1983 & 1 & 0.50 & Telecommunication & 14 & 6.97 \\
\hline 1985 & 4 & 1.99 & Energy & 54 & 26.87 \\
\hline 1986 & 5 & 2.49 & Other & 45 & 22.39 \\
\hline 1987 & 3 & 1.49 & Total & 201 & 100 \\
\hline 1988 & 4 & 1.99 & \multicolumn{3}{|c|}{ By Legal O rigin } \\
\hline 1989 & 25 & 12.44 & Category (countries) & Number & Percentage \\
\hline 1990 & 21 & 10.45 & Common law countries (10) & 65 & 32.34 \\
\hline 1991 & 34 & 16.92 & French civil law countries (20) & 131 & 65.17 \\
\hline 1992 & 30 & 14.93 & German civil law countries (2) & 5 & 2.49 \\
\hline 1993 & 11 & 5.47 & Total (32) & 201 & 100 \\
\hline 1994 & 17 & 8.46 & \multicolumn{3}{|c|}{ By Region* } \\
\hline 1995 & 9 & 4.48 & Region (countries) & Number & Percentage \\
\hline 1996 & 15 & 7.46 & A frica and the Middle East (10) & 49 & 24.38 \\
\hline \multirow[t]{3}{*}{1997} & 20 & 9.95 & East and South Asia and the Pacific (10) & 50 & 24.88 \\
\hline & & & Latin A merica and the Caribbean (9) & 67 & 33.33 \\
\hline & & & Europe and Central Asia (3) & 35 & 17.41 \\
\hline Total & 201 & 100 & Total (32) & 201 & 100 \\
\hline
\end{tabular}

* World Bank country group classifications. 
William Davidson Institute Working Paper 419

Table 2

\section{Summary of the Variables}

This table describes the variables used in the regression analysis to investigate the determinants of post-privatization performance changes.

\begin{tabular}{ll}
\hline Variables & Definition \\
\hline
\end{tabular}

\section{Operating Performance}

DROS

DSALEFF

DCESA

DSAL

\section{Economic Reforms and Environment}

$\Delta$ GDP

Liber

$\Delta$ Trade

Free

\section{Corporate Governance}

Control

Foreign

Law

Turn

Governance

\section{Control Variables}

Size

Industry Indicators
Change in return on sales during the privatization window $(-3,-1$ versus $+1,+3)$.

Change in sales efficiency during the privatization window $(-3,-1$ versus $+1,+3)$.

Change in capital expenditures during the privatization window $(-3,-1$ versus $+1,+3)$.

Change in real sales during the privatization window $(-3,-1$ versus $+1,+3)$.

Change of GDP growth rate over the privatization window $(-3,-1$ versus $+1,+3)$.

Indicator variable that takes the value of 1 if the privatization occurs after the stock market liberalization and 0 otherwise.

Change of the sum of exports and imports over GDP during the privatization window $(-3,-1$ versus $+1,+3)$.

The value of the economic freedom index before privatization.

Indicator variable that takes the value of 1 if the government relinquishes control of the privatized firm and 0 otherwise.

Indicator variable that takes the value of 1 if foreign investors are involved for the first time in the ownership structure of the privatized firm and 0 otherwise.

Indicator variable that takes the value of 1 for firms from common law countries and 0 otherwise.

Measure of stock market liquidity before privatization.

Measure of the extent of legal protections and enforcement before privatization that comprises 3 components: rule of law, risk of confiscation and risk of contract repudiation by the government.

The natural logarithm of total sales at the time of privatization.

Indicator variables included for 4 of the 5 industries defined in Table 1. 
Table $3 a$

\section{Descriptive Data on the Sample Countries}

This table provides some descriptive statistics on the macroeconomic and corporate governance variables for the sample of 32 countries. Details on the variables are presented below the table.

\begin{tabular}{|c|c|c|c|c|c|c|c|c|}
\hline \multirow[b]{2}{*}{ Country } & \multicolumn{6}{|c|}{ Panel A: Country-Level Macroeconomic Variables } & \multicolumn{2}{|c|}{$\begin{array}{c}\text { Panel B: Country-Level } \\
\text { Corporate Governance Variables }\end{array}$} \\
\hline & $\begin{array}{l}\text { Index of } \\
\text { Economic } \\
\text { Freedom } \\
\text { Mean 1980-97 }\end{array}$ & $\begin{array}{c}\text { Stock Market } \\
\text { Liberal ization } \\
\text { Date }\end{array}$ & $\begin{array}{c}\text { Foreign Direct } \\
\text { Investment/ GDP } \\
\text { Mean 1980-99 }\end{array}$ & $\begin{array}{c}\text { Trade } \\
\text { Liberalization } \\
\text { Date } \\
\end{array}$ & $\begin{array}{c}\text { Trade/ GDP } \\
\text { Mean 1980-99 }\end{array}$ & $\begin{array}{l}\text { GDP Growth } \\
\text { (annual \%) } \\
\text { Mean 1980-99 }\end{array}$ & $\begin{array}{c}\text { Stock Market } \\
\text { Turnover } \\
\text { Mean 1980-97 }\end{array}$ & $\begin{array}{l}\text { Governance } \\
\text { Index } \\
\text { Mean 1980-97 }\end{array}$ \\
\hline Bangladesh & 3.86 & $\mathrm{NL}$ & 0.07 & $\mathrm{NL}^{* *}$ & 23.11 & 4.56 & 33.76 & 3.60 \\
\hline Ghana & 4.40 & 1994 & 0.74 & 1985 & 43.58 & 3.13 & 2.98 & 4.98 \\
\hline India & 4.66 & 1992 & 0.22 & 1994 & 18.88 & 5.79 & 49.06 & 5.98 \\
\hline Malaysia & 7.44 & 1988 & 4.36 & Always open & 145.06 & 6.54 & 30.56 & 7.28 \\
\hline Nigeria & 3.68 & 1995 & 2.88 & $\mathrm{NL}^{*}$ & 60.80 & 1.99 & 0.99 & 3.44 \\
\hline Pakistan & 4.60 & 1991 & 0.61 & $N L *$ & 36.53 & 5.44 & 24.77 & 4.36 \\
\hline Singapore & 8.86 & Before 1969 & 9.67 & Always open & 370.44 & 7.54 & 40.27 & 9.18 \\
\hline Africa (South) & 6.28 & 1992 & 0.31 & 1991 & 48.06 & 1.79 & 12.48 & 6.18 \\
\hline Thailand & 6.90 & 1987 & 1.78 & Always open & 70.69 & 6.26 & 61.57 & 7.30 \\
\hline Trinidad & 5.98 & $\mathrm{NL}$ & 4.75 & $\mathrm{NL} *$ & 80.78 & 1.64 & 1.76 & 5.80 \\
\hline English Origin Average & 5.67 & N.A. & 254 & N.A. & 89.79 & 4.47 & 25.82 & 5.81 \\
\hline Argentina & 5.96 & 1989 & 1.58 & 1991 & 16.96 & 1.91 & 28.84 & 5.88 \\
\hline Brazil & 4.60 & 1991 & 1.08 & 1991 & 17.89 & 2.40 & 45.47 & 6.78 \\
\hline Chile & 7.14 & 1992 & 3.23 & 1976 & 55.95 & 5.41 & 7.41 & 7.08 \\
\hline Colombia & 5.38 & 1991 & 1.70 & 1991 & 31.91 & 3.12 & 9.15 & 4.40 \\
\hline Cote D'Ivoire & 5.22 & $N L$ & 1.04 & $N L^{* *}$ & 71.39 & 1.30 & 2.17 & 4.95 \\
\hline Egypt & 5.12 & 1997 & 1.96 & $\mathrm{NL}$ & 54.22 & 5.20 & 28.78 & 5.28 \\
\hline Greece & 6.24 & 1987 & 1.08 & 1959 & 44.24 & 1.94 & 17.61 & 6.78 \\
\hline Indonesia & 6.48 & 1989 & 0.71 & 1970 & 52.40 & 5.59 & 30.59 & 5.60 \\
\hline Jamaica & 5.92 & NL & 2.08 & 1988 & 107.76 & 1.09 & 7.13 & 5.64 \\
\hline Jordan & 5.76 & 1995 & 1.07 & 1965 & 121.18 & 4.43 & 14.96 & 4.52 \\
\hline Mexico & 6.18 & 1989 & 1.58 & 1986 & 39.20 & 2.82 & 51.48 & 6.84 \\
\hline Morocco & 5.06 & 1997 & 0.56 & 1984 & 55.76 & 3.25 & 20.65 & 5.20 \\
\hline Peru & 4.96 & N.A. & 1.53 & 1991 & 32.32 & 1.82 & 29.95 & 4.72 \\
\hline Philippines & 6.24 & 1991 & 1.14 & 1988 & 66.58 & 2.38 & 27.16 & 4.22 \\
\hline
\end{tabular}


William Davidson Institute Working Paper 419

Table 3a-- Continued

\begin{tabular}{|c|c|c|c|c|c|c|c|c|}
\hline \multirow[b]{2}{*}{ Country } & \multicolumn{6}{|c|}{ Panel A: Country-Level Macroeconomic Variables } & \multicolumn{2}{|c|}{$\begin{array}{c}\text { Panel B: Country-Level } \\
\text { Corporate Governance Variables } \\
\end{array}$} \\
\hline & $\begin{array}{l}\text { Index of } \\
\text { Economic } \\
\text { Freedom } \\
\text { Mean 1980-97 }\end{array}$ & $\begin{array}{c}\text { Stock Market } \\
\text { Liberalization } \\
\text { Date }\end{array}$ & $\begin{array}{c}\text { Foreign Direct } \\
\text { Investment/ GDP } \\
\text { Mean 1980-99 }\end{array}$ & $\begin{array}{c}\text { Trade } \\
\text { Liberalization } \\
\text { Date }\end{array}$ & $\begin{array}{l}\text { Trade/ GDP } \\
\text { Mean 1980-98 }\end{array}$ & $\begin{array}{l}\text { GDP Growth } \\
\text { (annual \%) } \\
\text { Mean 1980-99 }\end{array}$ & $\begin{array}{c}\text { Stock Market } \\
\text { Turnover } \\
\text { Mean 1980-97 }\end{array}$ & $\begin{array}{l}\text { Legal and } \\
\text { Institutional } \\
\text { Index } \\
\text { Mean 1980-97 }\end{array}$ \\
\hline Portugal & 6.70 & 1986 & 1.54 & 1960 & 66.61 & 2.99 & 40.70 & 8.78 \\
\hline Senegal & 4.76 & N.A. & 0.65 & $N L^{* *}$ & 67.72 & 2.88 & N.A. & 3.06 \\
\hline Togo & 4.90 & N.L. & 1.01 & $N L^{*}$ & 84.60 & 2.14 & N.A. & 4.12 \\
\hline Tunisia & 5.18 & $N L$ & 1.96 & 1989 & 84.54 & 4.33 & 1.45 & 5.16 \\
\hline Turkey & 5.16 & 1989 & 0.33 & 1989 & 35.78 & 4.04 & 67.08 & 5.50 \\
\hline Venezuela & 5.80 & 1990 & 1.38 & 1990 & 48.20 & 1.07 & 15.76 & 5.68 \\
\hline French Origin Average & 5.64 & N.A. & 1.36 & N.A. & 57.76 & 3.01 & 24.80 & 5.51 \\
\hline Korea (S) & 6.66 & 1992 & 0.47 & 1968 & 67.10 & 7.06 & 96.17 & 7.22 \\
\hline Taiwan & 7.28 & 1991 & N.A. & 1963 & N.A. & N.A. & N.A & 8.64 \\
\hline German Origin Average & 6.97 & N.A. & 0.47 & N.A. & 66.51 & 7.06 & 96.17 & 7.93 \\
\hline \multicolumn{9}{|l|}{ Developed Countries } \\
\hline Japan & 7.98 & 1980 & 0.04 & 1962 & 21.25 & 2.72 & 39.75 & 9.28 \\
\hline United Kingdom & 8.26 & Before 1969 & 2.13 & 1959 & 52.74 & 2.19 & 47.925 & 9.14 \\
\hline \multirow[t]{2}{*}{ United States } & 8.76 & Before 1969 & 0.95 & 1950 & 20.44 & 2.99 & 83.775 & 9.62 \\
\hline & $\begin{array}{c}\text { Source: } \\
\text { Gwartney, } \\
\text { Lawson and } \\
\text { Samida (2000) }\end{array}$ & $\begin{array}{c}\text { Source: Bekaert, } \\
\text { Harvey and } \\
\text { Lundblad } \\
\text { (2001a) and } \\
\text { Henry (2000) }\end{array}$ & $\begin{array}{c}\text { Source: World } \\
\text { Development } \\
\text { Indicators (2001) }\end{array}$ & $\begin{array}{c}\text { Source: Sachs } \\
\text { and Warner } \\
\text { (1995) and IMF } \\
\text { Country } \\
\text { Reports }\end{array}$ & $\begin{array}{l}\text { Source: World } \\
\text { Development } \\
\text { Indicators } \\
(2001)\end{array}$ & $\begin{array}{c}\text { Source: World } \\
\text { Development } \\
\text { Indicators (2001) }\end{array}$ & $\begin{array}{l}\text { Source: World } \\
\text { Development } \\
\text { Indicators } \\
(2001)\end{array}$ & $\begin{array}{c}\text { Source: Gwartney, } \\
\text { Lawson and } \\
\text { Samida (2000) }\end{array}$ \\
\hline
\end{tabular}

* Not liberalized by 1992 .

** Not liberalized by 1997.

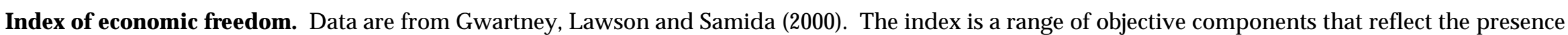

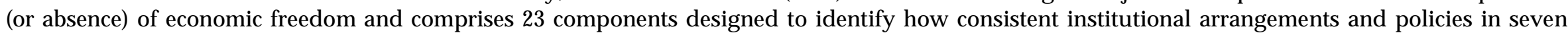

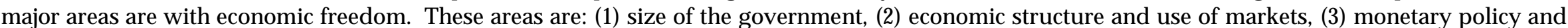

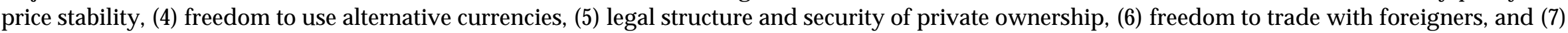
freedom to exchange in capital markets. Scale from 0 to 10, with higher scores indicating higher levels of economic freedom. 
Table 3a-- Continued

Stodk market liberalization date. Data are from Bekaert, Harvey and Lundblad (2001a). The liberalization date for Taiwan is from Bekaert and Harvey (2000). NL indicates that the stock market is not liberalized. Missing countries are: Peru and Senegal.

Trade liberalization date. Data are from Sachs and Warner (1995) and IMF Country Reports.

Trade/GDP. The ratio is the sum of exports and imports of goods and services divided by gross domestic product (GDP hereafter). Data are from the World Development Indicators (2001) CD-ROM and are available from 1980 to 1999.

GDP growth. Annual percentage growth rate of GDP at market prices based on constant local currency. Aggregates are based on constant 1995 U.S. dollars. Data are from the World Development Indicators (2001) CD-ROM and are available from 1980 to 1999.

Stock market tumover. Total value of shares traded during the period divided by the average market capitalization for the period. Data are from the World Development Indicators (2001) CD-ROM and are available from 1980 to 1999.

Govemance index. The index focuses on the legal structure and the security of property rights and the enforcement of contracts. It comprises the following three components: (1) rule of law (countries with legal institutions that were more supportive of rule of law received higher ratings), (2) risk of expropriation (countries with less risk of confiscation received higher ratings), and (3) risk of contract repudiation (countries where there is less risk that government will unilaterally cancel contracts received higher ratings). Data are from Gwartney, Lawson and Samida (2000) and are available from 1980 to 1997. All components of the index are from the International Country Risk Guide. 
Table 3b

\section{Firm Characteristics}

This table presents summary statistics on the government and foreign ownership after privatization for a subsample of 192 firms privatized between 1980 and 1997. It also reports the post-privatization size of the firms as measured by the natural logarithm of sales. The post-privatization data come mainly from annual reports and offering prospectus. All statistics are presented as a percentage.

\begin{tabular}{|c|c|c|c|c|c|c|c|c|c|}
\hline & \multicolumn{3}{|c|}{$\begin{array}{c}\text { Post-Privatization } \\
\text { Government Ownership (\%) }\end{array}$} & \multicolumn{3}{|c|}{$\begin{array}{l}\text { Post-Privatization Foreign } \\
\text { Ownership (\%) }\end{array}$} & \multicolumn{3}{|c|}{$\begin{array}{l}\text { Size (natural logarithm of } \\
\text { sales) }\end{array}$} \\
\hline & $\mathrm{N}$ & Mean & Median & $\mathrm{N}$ & Mean & Median & $\mathrm{N}$ & Mean & Median \\
\hline \multicolumn{10}{|l|}{ Legal Origin } \\
\hline Common Law & 63 & 32.49 & 30 & 61 & 14.09 & 6.00 & 63 & 11.23 & 11.39 \\
\hline Civil Law & 119 & 24.52 & 5 & 90 & 18.29 & 4.40 & 129 & 12.25 & 12.61 \\
\hline \multicolumn{10}{|l|}{ Region } \\
\hline A frica and the Middle East & 45 & 21.14 & 13.14 & 44 & 19.86 & 7.04 & 44 & 10 & 10.12 \\
\hline Latin America and the Caribbean & 61 & 13.27 & 0 & 39 & 26.12 & 9 & 64 & 12.74 & 12.95 \\
\hline East and South A sia and the Pacific & 47 & 52.32 & 65 & 45 & 9.95 & 6.83 & 49 & 12.83 & 12.99 \\
\hline Europe and Central Asia & 29 & 24.79 & 13.20 & 23 & 7.20 & 0 & 35 & 11.57 & 12.28 \\
\hline \multicolumn{10}{|l|}{ Industry } \\
\hline Financial & 63 & 14.26 & 0 & 50 & 22.13 & 9.17 & 66 & 11.30 & 12.11 \\
\hline Utilities & 22 & 37.14 & 40.27 & 17 & 19.81 & 7.90 & 22 & 12.23 & 13.35 \\
\hline Telecommunication & 14 & 37.13 & 41.35 & 11 & 30.63 & 33 & 12 & 13.61 & 13.59 \\
\hline Energy & 46 & 36.99 & 30.50 & 39 & 11.82 & 2 & 52 & 12.23 & 12.16 \\
\hline Other & 36 & 28.99 & 24.53 & 32 & 8.29 & 0.15 & 40 & 11.84 & 12.26 \\
\hline
\end{tabular}




\section{Table 4}

\section{Summary of Results for the Sample of All Privatized Firms: 1980-1997}

This table presents the univariate results for the complete sample of privatized firms in developing countries for the period 1980-1997. The measures of operating performance are return on sales (ROS), return on assets (ROA), return on equity (ROE), sales efficiency (SALEFF), net income efficiency (NIEFF), capital expenditures divided by sales (CESA), capital expenditures divided by total assets (CETA) and real sales (SAL). For each performance measure, it provides the mean and the median values for the three-year period before and after privatization. Column 5 presents the change in the mean and median values of the performance indicators after versus before privatization. Column 6 provides the Wilcoxon $Z$ statistic for the difference in medians. The two remaining columns provide the proportion of firms whose performance changed as predicted and the significance test of this change. $*$, **, *** denote significance levels of 1,5 and 10 percent, respectively.

\begin{tabular}{|c|c|c|c|c|c|c|c|}
\hline Variables & $\mathrm{N}$ & $\begin{array}{c}\text { Mean } \\
\text { (Median) } \\
\text { Before }\end{array}$ & $\begin{array}{c}\text { Mean } \\
\text { (Median) } \\
\text { After }\end{array}$ & $\begin{array}{c}\text { Mean } \\
\text { (Median) } \\
\text { Change }\end{array}$ & $\begin{array}{c}\text { Z-Statistic for } \\
\text { Difference in } \\
\text { Medians } \\
\text { (A fter-Before) }\end{array}$ & $\begin{array}{l}\text { Proportion of } \\
\text { Firms that } \\
\text { Behaved as } \\
\text { Predicted }\end{array}$ & $\begin{array}{c}\text { Z-Statistic for } \\
\text { Significance of } \\
\text { Proportion } \\
\text { Change }\end{array}$ \\
\hline \multicolumn{8}{|l|}{ Profitability } \\
\hline Return on Sales (ROS) & 196 & $\begin{array}{c}0.073 \\
(0.049)\end{array}$ & $\begin{array}{c}0.149 \\
(0.090)\end{array}$ & $\begin{array}{c}0.077 \\
(0.023)\end{array}$ & $4.08^{*}$ & 0.61 & $3.22 *$ \\
\hline Return on Assets (ROA) & 199 & $\begin{array}{c}0.044 \\
(0.024)\end{array}$ & $\begin{array}{c}0.057 \\
(0.039)\end{array}$ & $\begin{array}{c}0.012 \\
(0.010)\end{array}$ & $2.98 *$ & 0.62 & $3.57^{*}$ \\
\hline Return on Equity (ROE) & 198 & $\begin{array}{c}0.166 \\
(0.102)\end{array}$ & $\begin{array}{c}0.204 \\
(0.140)\end{array}$ & $\begin{array}{c}0.038 \\
(0.023)\end{array}$ & $2.56^{*}$ & 0.59 & $2.45^{* *}$ \\
\hline \multicolumn{8}{|l|}{ Efficiency } \\
\hline Sales Efficiency (SA LEFF) & 127 & $\begin{array}{c}0.967 \\
(0.932)\end{array}$ & $\begin{array}{c}1.319 \\
(1.115)\end{array}$ & $\begin{array}{c}0.352 \\
(0.197)\end{array}$ & $7.04 *$ & 0.74 & $6.15^{*}$ \\
\hline Net Income Efficiency (NIEFF) & 123 & $\begin{array}{c}0.879 \\
(0.791)\end{array}$ & $\begin{array}{c}1.406 \\
(1.216)\end{array}$ & $\begin{array}{c}0.527 \\
(0.357)\end{array}$ & $4.39 *$ & 0.65 & $3.48^{*}$ \\
\hline \multicolumn{8}{|l|}{ Investment } \\
\hline Capital Expenditures to Sales (CESA) & 149 & $\begin{array}{c}0.122 \\
(0.042)\end{array}$ & $\begin{array}{c}0.213 \\
(0.095)\end{array}$ & $\begin{array}{c}0.091 \\
(0.022)\end{array}$ & $4.00^{*}$ & 0.72 & $5.90^{*}$ \\
\hline Capital Expenditures to Total Assets (CETA) & 149 & $\begin{array}{c}0.056 \\
(0.013)\end{array}$ & $\begin{array}{c}0.083 \\
(0.048)\end{array}$ & $\begin{array}{c}0.027 \\
(0.011)\end{array}$ & $3.62^{*}$ & 0.68 & $4.83^{*}$ \\
\hline \multicolumn{8}{|l|}{ Output } \\
\hline Real Sales (SAL) & 198 & $\begin{array}{c}1.147 \\
(0.939)\end{array}$ & $\begin{array}{c}1.294 \\
(1.128)\end{array}$ & $\begin{array}{c}0.147 \\
(0.159)\end{array}$ & $6.64^{*}$ & 0.72 & $6.77^{*}$ \\
\hline \multicolumn{8}{|l|}{ Employment } \\
\hline Total Number of Employees (EMPL) & 128 & $\begin{array}{l}11396 \\
(3545)\end{array}$ & $\begin{array}{l}11280 \\
(3765)\end{array}$ & $\begin{array}{c}-116 \\
(9)\end{array}$ & -0.09 & 0.53 & 0.71 \\
\hline
\end{tabular}


Table 5

Summary of Market-Adjusted and Unadjusted Results for the Sample of Market-Adjusted Fims

This table presents both unadjusted and adjusted results for the sample of firms for which we could compute market-adjusted accounting performance measures. Market-adjusted performance measures are obtained by subtracting the market median performance measure from the firm's performance measure. The measures of operating performance are return on sales (ROS), sales efficiency (SALEFF), capital expenditures divided by sales (CESA) and real sales $(S A L)$. For each performance measure, the mean and the median values are computed over a window of $-3,-1$ and $+1,+3$ years around the privatization year. Column 5 presents the change in the mean and median values of performance indicators after versus before privatization. Column 6 provides the Wilcoxon $Z$ statistic for the difference in medians. The two remaining columns provide the proportion of firms whose performance changed as predicted and the significance test of this change. *, **, *** denote significance levels of 1,5 and 10 percent, respectively.

\begin{tabular}{|c|c|c|c|c|c|c|c|}
\hline Variables & $\mathrm{N}$ & $\begin{array}{l}\text { Mean } \\
\text { (Median) } \\
\text { Before } \\
\end{array}$ & $\begin{array}{l}\text { Mean } \\
\text { (Median) } \\
\text { After }\end{array}$ & $\begin{array}{l}\text { Mean } \\
\text { (M edian) } \\
\text { Change }\end{array}$ & $\begin{array}{l}\text { Z-Statistic for } \\
\text { Difference in } \\
\text { Medians } \\
\text { (After-Before) }\end{array}$ & $\begin{array}{c}\text { Proportion of Firms } \\
\text { that Behaved as } \\
\text { Predicted }\end{array}$ & $\begin{array}{c}\text { Z-Statistic for } \\
\text { Significance of } \\
\text { Proportion Change }\end{array}$ \\
\hline \multicolumn{8}{|c|}{ Retum on Sales } \\
\hline Unadjusted & 110 & $\begin{array}{c}0.045 \\
(0.042)\end{array}$ & $\begin{array}{c}0.147 \\
(0.085)\end{array}$ & $\begin{array}{c}0.102 \\
(0.025)\end{array}$ & $3.60^{*}$ & 0.64 & $2.96 *$ \\
\hline Adjusted & 110 & $\begin{array}{c}-0.066 \\
(-0.018)\end{array}$ & $\begin{array}{c}0.083 \\
(0.040)\end{array}$ & $\begin{array}{c}0.149 \\
(0.047)\end{array}$ & $4.08 *$ & 0.65 & $3.39 *$ \\
\hline \multicolumn{8}{|c|}{ Sales Efficiency } \\
\hline Unadjusted & 66 & $\begin{array}{c}0.944 \\
(0.908)\end{array}$ & $\begin{array}{c}1.402 \\
(1.157)\end{array}$ & $\begin{array}{c}0.457 \\
(0.263)\end{array}$ & $5.83^{*}$ & 0.79 & $5.68^{*}$ \\
\hline Adjusted & 66 & $\begin{array}{c}-0.092 \\
(-0.083)\end{array}$ & $\begin{array}{c}0.398 \\
(0.175)\end{array}$ & $\begin{array}{c}0.490 \\
(0.208)\end{array}$ & $4.34^{*}$ & 0.70 & $3.46^{*}$ \\
\hline \multicolumn{8}{|c|}{ Capital Expenditures to Sales } \\
\hline Unadjusted & 69 & $\begin{array}{c}0.188 \\
(0.079)\end{array}$ & $\begin{array}{c}0.232 \\
(0.116)\end{array}$ & $\begin{array}{c}0.044 \\
(0.017)\end{array}$ & $1.92^{* *}$ & 0.67 & $2.92^{*}$ \\
\hline Adjusted & 69 & $\begin{array}{c}0.149 \\
(0.039)\end{array}$ & $\begin{array}{c}0.192 \\
(0.068)\end{array}$ & $\begin{array}{c}0.043 \\
(0.013)\end{array}$ & $1.83^{* 1 *}$ & 0.61 & $1.84^{* 1 *}$ \\
\hline \multicolumn{8}{|l|}{ Real Sales } \\
\hline Unadjusted & 100 & $\begin{array}{c}1.272 \\
(0.921)\end{array}$ & $\begin{array}{c}1.314 \\
(1.128)\end{array}$ & $\begin{array}{c}0.042 \\
(0.185)\end{array}$ & $5.67 *$ & 0.74 & $5.44^{*}$ \\
\hline Adjusted & 100 & $\begin{array}{c}0.256 \\
(-0.012)\end{array}$ & $\begin{array}{c}0.342 \\
(0.107)\end{array}$ & $\begin{array}{c}0.087 \\
(0.122)\end{array}$ & $3.93^{*}$ & 0.59 & $1.82^{*}+*$ \\
\hline
\end{tabular}


Table 6

Performance Changes of Newly Privatized Firms by Geographical Region

This table reports the changes in performance for the sample of 201 privatized firms classified in four geographical regions according to the four World Bank country group classifications: (1) Africa and the Middle East, (2) East and South Asia and the Pacific, (3) Latin America and the Caribbean and (4) Europe and Central Asia. The measures of operating performance are return on sales (ROS), return on assets (ROA), return on equity (ROE), sales efficiency (SALEFF), net income efficiency (NIEFF), capital expenditures divided by sales (CESA), capital expenditures divided by total assets (CETA) and real sales (SAL). For each performance measure, the table provides the change in the mean and median values, the Wilcoxon $Z$ statistic for the difference in medians and the number of observations. It also presents the p-value of the multi-sample non parametric Savage test for the difference between the four regions. *, **, *** denote significance levels of 1, 5 and 10 percent, respectively.

\begin{tabular}{|c|c|c|c|c|c|c|c|c|}
\hline \multirow{2}{*}{$\begin{array}{l}\text { Performance } \\
\text { Region }\end{array}$} & \multicolumn{3}{|c|}{ Profitability } & \multicolumn{2}{|c|}{ Efficiency } & \multicolumn{2}{|c|}{ Investment } & \multirow{2}{*}{$\begin{array}{c}\text { Output } \\
\text { SAL }\end{array}$} \\
\hline & ROS & ROA & ROE & SALEFF & NIEFF & CESA & CETA & \\
\hline \multicolumn{9}{|l|}{ A frica and the Middle East } \\
\hline Mean change & 0.033 & 0.013 & 0.032 & -0.003 & -1.176 & 0.117 & 0.053 & 0.013 \\
\hline Median change & 0.009 & 0.010 & 0.017 & -0.024 & -0.088 & 0.033 & 0.017 & 0.020 \\
\hline Z-stat Wilcoxon test & 1.15 & 1.04 & 1.02 & 0.07 & 0.20 & $2.91 *$ & $3.05^{*}$ & 0.33 \\
\hline $\mathrm{N}$ & 46 & 48 & 47 & 11 & 11 & 42 & 44 & 48 \\
\hline \multicolumn{9}{|l|}{ East and South Asia and thePacific } \\
\hline Mean change & 0.064 & 0.019 & 0.018 & 0.367 & 0.797 & 0.169 & 0.041 & 0.528 \\
\hline Median change & 0.024 & 0.011 & 0.025 & 0.176 & 0.521 & 0.022 & 0.019 & 0.179 \\
\hline Z-stat Wilcoxon test & $2.41^{* *}$ & $2.05^{* *}$ & 1.44 & $3.86 *$ & $4.00^{*}$ & $1.84^{* * *}$ & $1.66^{k 1 k k}$ & $6.07 *$ \\
\hline $\mathrm{N}$ & 50 & 49 & 50 & 41 & 41 & 40 & 38 & 50 \\
\hline \multicolumn{9}{|l|}{ Latin A merica and the Cari bbean } \\
\hline Mean change & 0.108 & 0.034 & 0.093 & 0.485 & 0.760 & 0.009 & 0.003 & 0.324 \\
\hline Median change & 0.077 & 0.013 & 0.077 & 0.362 & 0.478 & 0.027 & 0.011 & 0.294 \\
\hline Z-stat Wilcoxon test & $3.55^{*}$ & $3.44^{*}$ & $3.12 *$ & $5.27 *$ & $3.28 *$ & $2.25^{* *}$ & $2.13^{* *}$ & 4.59 \\
\hline $\mathrm{N}$ & 66 & 67 & 67 & 48 & 46 & 53 & 53 & 65 \\
\hline \multicolumn{9}{|l|}{ Europeand Central Asia } \\
\hline Mean change & 0.090 & -0.044 & -0.037 & 0.137 & -0.257 & 0.075 & -0.004 & -0.002 \\
\hline Median change & 0.001 & -0.003 & -0.032 & 0.229 & -0.136 & -0.005 & -0.002 & 0.138 \\
\hline Z-stat Wilcoxon test & 0.09 & -0.76 & -0.69 & $2.41^{* *}$ & -0.81 & 0.15 & -0.67 & $2.93^{*}$ \\
\hline $\mathrm{N}$ & 34 & 35 & 34 & 21 & 21 & 13 & 13 & 34 \\
\hline $\begin{array}{l}\text { P-value Savage test (difference } \\
\text { between regions) }\end{array}$ & $0.00^{*}$ & $0.09 * 12 k$ & $0.05^{\text {*k }}$ & $0.01 *$ & 0.09 kak & 0.74 & 0.11 & $0.00^{*}$ \\
\hline
\end{tabular}


Table 7

Comparison of Performance Changes: The Role of Economic Reforms and Environment

This table presents comparisons between the operating performance changes of several partitions of privatized firms based on economic reforms and environment variables. The measures of operating performance are return on sales (ROS), sales efficiency (SALEFF), capital expenditures divided by sales (CESA), and real sales $(S A L)$. Panel A compares the performance changes of firms privatized before trade liberalization (BTL) versus those privatized after trade liberalization (ATL). The effective trade liberalization dates are from Sachs and Warner (1995). Panel B compares the performance changes of firms privatized before stock market liberalization (BSL) versus those privatized after stock market liberalization (ASL). Panel C compares the performance changes of privatized firms in countries with low economic freedom (LEF) versus those from countries with high economic freedom (HEF). The index is from Gwartney, Lawson and Samida (2000) and covers the period 1980-1997. For each performance measure, the table provides the change in the mean and median values, the Wilcoxon $Z$ statistic for the difference in medians and the number of observations. It also presents the $p$-value of the Kruskal-Wallis test for the difference between the two subsamples. *, **, *** denote significance levels of 1, 5 and 10 percent, respectively.

\begin{tabular}{|c|c|c|c|c|}
\hline M easures of Operating Performance & ROS & SALEFF & CESA & SAL \\
\hline \multicolumn{5}{|c|}{ Panel A. Performance Changes for Privatized Firms before versus after Trade Liberalization } \\
\hline \multicolumn{5}{|l|}{ BTL } \\
\hline Mean change & 0.035 & 0.120 & 0.092 & 0.092 \\
\hline Median change & 0.009 & 0.128 & 0.019 & 0.059 \\
\hline Z-stat Wilcoxon test & 1.51 & $2.33^{* *}$ & $3.07 *$ & $1.88^{* * 1 *}$ \\
\hline $\mathrm{N}$ & 51 & 29 & 43 & 53 \\
\hline \multicolumn{5}{|l|}{ ATL } \\
\hline M ean change & 0.092 & 0.443 & 0.093 & 0.315 \\
\hline Median change & 0.039 & 0.271 & 0.031 & 0.215 \\
\hline Z-stat Wilcoxon test & $3.61^{*}$ & $6.71^{*}$ & $2.86^{*}$ & $6.95^{*}$ \\
\hline $\mathrm{N}$ & 138 & 93 & 102 & 137 \\
\hline $\begin{array}{l}\text { P-value Kruskal-Wallis test for } \\
\text { difference between subsamples }\end{array}$ & $0.03^{* *}$ & $0.01^{*}$ & 0.59 & $0.02^{* *}$ \\
\hline \multicolumn{5}{|c|}{ Panel B. Performance C hanges for Privatized Firms before versus after Stock M arket Liberalization } \\
\hline \multicolumn{5}{|l|}{ BSL } \\
\hline Mean change & 0.046 & 0.094 & 0.088 & 0.082 \\
\hline Median change & 0.021 & 0.104 & 0.028 & 0.079 \\
\hline Z-stat Wilcoxon test & $2.05^{* *}$ & $1.85^{* 14 *}$ & $3.51^{*}$ & $1.95^{* *}$ \\
\hline $\mathrm{N}$ & 76 & 37 & 66 & 78 \\
\hline \multicolumn{5}{|l|}{ ASL } \\
\hline Mean change & 0.096 & 0.461 & 0.090 & 0.353 \\
\hline Median change & 0.021 & 0.271 & 0.017 & 0.229 \\
\hline Z-stat Wilcoxon test & 2.97 & 6.70 & 1.84 & 6.79 \\
\hline $\mathrm{N}$ & 110 & 84 & 74 & 109 \\
\hline $\begin{array}{l}\text { P-value Kruskal-Wallis test for } \\
\text { difference between Subsamples }\end{array}$ & 0.44 & $0.00^{*}$ & 0.64 & $0.00^{*}$ \\
\hline
\end{tabular}


William Davidson Institute Working Paper 419

Table 7 -- Continued

\begin{tabular}{lcccc}
\hline M easures of Operating Performance & ROS & SA LEFF & CESA & SAL \\
\hline \multicolumn{2}{c}{ Panel C. Performance Changes for Privatized Firms in Countries with Low versus High Economic Freedom } \\
\hline LEF & & & & \\
Mean change & 0.081 & 0.244 & 0.052 & 0.030 \\
Median change & 0.033 & 0.162 & 0.018 & 0.092 \\
Z-stat Wilcoxon test & $2.91^{*}$ & $3.58^{*}$ & $3.00^{*}$ & $2.71^{*}$ \\
N & 116 & 63 & 86 & 117 \\
HEF & & & & 0.555 \\
Mean change & 0.071 & 0.458 & 0.144 & 0.294 \\
Median change & 0.019 & 0.270 & 0.029 & $7.72^{*}$ \\
Z-stat Wilcoxon test & $2.77^{*}$ & $6.33^{*}$ & $2.61^{*}$ & 80 \\
N & 80 & 64 & 63 & $0.00^{*}$ \\
\hline P-value Kruskal-Wallis test for & 0.71 & $0.03^{* *}$ & 0.53 & \\
difference between subsamples & & & & \\
\hline
\end{tabular}


Table 8

Comparison of Performance Changes: The Role of Corporate G overnance

This table presents comparisons between the operating performance changes of several partitions of privatized firms based on corporate governance variables. The measures of operating performance are return on sales (ROS), sales efficiency (SALEFF), capital expenditures divided by sales (CESA), and real sales (SAL). Panel A compares the performance changes of control privatization (more than $50 \%$ of the company is privatized) and revenue privatization (less than $50 \%$ of the company is privatized). Panel $\mathrm{B}$ compares the performance changes of privatized firms without foreign ownership (NFO) or with foreign ownership after privatization (FO). Panel C compares the performance changes for privatized firms with a new CEO during the privatization process versus privatized firms with the same CEO. Panel $D$ compares the performance changes for privatized firms in countries with low governance index (LGI) versus high governance index (HGI). The index is from Gwartney, Lawson and Samida (2000) and covers the period 1980-1997. For each performance measure, it provides the change in mean and median values, the Wilcoxon $Z$ statistic for the difference in medians and the number of observations. It also presents the p-value of the Kruskal-Wallis test for the difference between the two subsamples. $*, * * * *$ denote significance levels of 1,5 and 10 percent, respectively.

\begin{tabular}{|c|c|c|c|c|}
\hline M easures of O perating Performance & ROS & SALEFF & CESA & SAL \\
\hline \multicolumn{5}{|c|}{ Panel A. Performance Changes for Revenue versus Control Privatization } \\
\hline \multicolumn{5}{|c|}{ C } \\
\hline Mean change & 0.128 & 0.596 & 0.115 & 0.464 \\
\hline Median change & 0.069 & 0.363 & 0.020 & 0.277 \\
\hline Z-stat Wilcoxon test & $4.04^{*}$ & $5.94 *$ & 3.13* & $5.62^{*}$ \\
\hline $\mathrm{N}$ & 85 & 59 & 70 & 85 \\
\hline \multicolumn{5}{|l|}{ Revenue } \\
\hline M ean change & 0.030 & 0.142 & 0.046 & 0.200 \\
\hline Median change & 0.011 & 0.088 & 0.063 & 0.113 \\
\hline Z-stat Wilcoxon test & $1.80^{* 1+k}$ & 3.35* & $1.82^{* * 1 *}$ & $4.76^{*}$ \\
\hline $\mathrm{N}$ & 69 & 52 & 49 & 69 \\
\hline $\begin{array}{l}\text { P-value Kruskal-Wallis Test for } \\
\text { Difference between Subsamples }\end{array}$ & $0.00^{*}$ & $0.00^{*}$ & 0.44 & $0.04^{* *}$ \\
\hline \multicolumn{5}{|c|}{ Panel B. Performance Changes for Privatized Firms with or without Foreign O wnership } \\
\hline \multicolumn{5}{|c|}{ ( } \\
\hline M ean change & 0.056 & 0.277 & 0.078 & 0.189 \\
\hline Median change & 0.004 & 0.191 & 0.029 & 0.183 \\
\hline Z-stat Wilcoxon test & 0.88 & $3.74^{*}$ & $3.13^{*}$ & 3.93* \\
\hline $\mathrm{N}$ & 80 & 47 & 61 & 80 \\
\hline \multicolumn{5}{|l|}{ FO } \\
\hline M ean change & 0.131 & 0.540 & 0.149 & 0.441 \\
\hline Median change & 0.082 & 0.277 & 0.027 & 0.238 \\
\hline Z-stat Wilcoxon test & $4.44^{*}$ & $5.79 *$ & $2.52 *$ & $6.30^{*}$ \\
\hline $\mathrm{N}$ & 71 & 54 & 55 & 71 \\
\hline $\begin{array}{l}\text { P-value Kruskal-Wall is test for } \\
\text { difference between subsamples }\end{array}$ & $0.00^{*}$ & 0.13 & 0.68 & 0.16 \\
\hline
\end{tabular}


William Davidson Institute Working Paper 419

Table 8 -- Continued

\begin{tabular}{|c|c|c|c|c|}
\hline M easures of Operating Performance & ROS & SALEFF & CESA & SAL \\
\hline \multicolumn{5}{|c|}{ Panel C. Performance Changes for Privatized Firms with or without CEO Change } \\
\hline \multicolumn{5}{|c|}{ 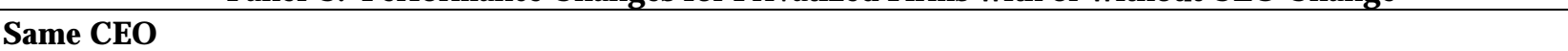 } \\
\hline Mean change & 0.042 & 0.183 & 0.148 & 0.092 \\
\hline Median change & 0.017 & 0.162 & 0.042 & 0.065 \\
\hline Z-stat Wilcoxon test & 1.28 & $2.90^{*}$ & $3.16^{*}$ & $2.54^{*}$ \\
\hline $\mathrm{N}$ & 47 & 33 & 43 & 48 \\
\hline \multicolumn{5}{|l|}{ New CEO } \\
\hline Mean change & 0.084 & 0.365 & 0.170 & 0.168 \\
\hline Median change & 0.063 & 0.231 & 0.013 & 0.136 \\
\hline Z-stat Wilcoxon test & $3.07^{*}$ & $3.98 *$ & $1.65^{* * *}$ & $2.50^{*}$ \\
\hline $\mathrm{N}$ & 34 & 26 & 25 & 34 \\
\hline $\begin{array}{l}\text { P-value Kruskal-Wallis test for } \\
\text { difference between subsamples }\end{array}$ & $0.05^{* *}$ & $0.10^{\text {kakk }}$ & 0.16 & 0.62 \\
\hline \multicolumn{5}{|c|}{ Panel D. Performance Changes for Privatized Firms in Countries with Less versus High G overnance Inde) } \\
\hline \multicolumn{5}{|l|}{ LG I } \\
\hline Mean change & 0.081 & 0.213 & 0.122 & 0.036 \\
\hline Median change & 0.036 & 0.129 & 0.039 & 0.075 \\
\hline Z-stat Wilcoxon test & $2.34 * *$ & $2.40^{\text {秋 }}$ & $3.82^{*}$ & $2.52^{*}$ \\
\hline $\mathrm{N}$ & 88 & 43 & 67 & 90 \\
\hline \multicolumn{5}{|l|}{ HG I } \\
\hline Mean change & 0.069 & 0.436 & 0.110 & 0.447 \\
\hline Median change & 0.019 & 0.271 & 0.019 & 0.229 \\
\hline Z-stat Wilcoxon test & $3.47^{*}$ & $7.19^{*}$ & $2.51^{*}$ & $7.75^{*}$ \\
\hline $\mathrm{N}$ & 105 & 83 & 79 & 105 \\
\hline $\begin{array}{l}\text { P-value Kruskal-Wallis test for } \\
\text { difference between subsamples }\end{array}$ & 0.83 & $0.01 *$ & 0.15 & $0.00^{*}$ \\
\hline
\end{tabular}




\section{Table 9}

\section{Coefficient Estimates from Regressions of Performance Changes of Privatized Firms on Economic Reforms and Environment and Corporate} Govemance Variables

This table presents the results from regressions conducted to determine the sources of performance changes of privatized firms in developing countries over the period 1980-1997. The dependent variables in the four Panels are change in return on sales (DROS), change in sales efficiency (DSALEFF), change in capital expenditures (DCESA) and change in real sales (DSAL), respectively. The change in each of the dependent variables is computed by substracting the three-yearpre-privatization average from the three-year-post-privatization average. The independent variables are related to economic reforms and environment and to corporate governance. They are described as follows: $\Delta$ GDP is the change of GDP growth during the privatization window $(-3,-1$ and $+1,+3)$; Liber takes the value of 1 if the privatization occurs after the stock market liberalization; $\Delta$ Trade is the change of the sum of exports and imports over GDP during the privatization window $(-3,-1$ and $+1,+3)$; Free is the value of the index of economic freedom before privatization; Control takes the value of 1 if the government relinquishes control of the privatized firm; Foreign equals 1 if foreign investors are involved in the ownership structure of the privatized firm; Law equals 1 for firms from common law countries; Governance is a measure of the extent of legal protections and law enforcement; Turn is the three-year-pre-privatization average turnover and measures the liquidity of the stock market. Size is the natural logarithm of total sales at the time of privatization. We include industry indicators in all specifications. Heteroskedasticity-consistent t-statistics using White's (1980) procedure are reported in parentheses. *, **, *** denote significance levels of 1, 5 and 10 percent, respectively.

\begin{tabular}{|c|c|c|c|c|c|c|c|c|c|c|c|c|c|c|c|}
\hline & \multirow[b]{2}{*}{ Const } & \multicolumn{4}{|c|}{$\begin{array}{c}\text { Economic Reforms and } \\
\text { Environment }\end{array}$} & \multicolumn{5}{|c|}{ Corporate Governance } & \multicolumn{2}{|c|}{ Control } & \multirow[b]{2}{*}{$A d j-R^{2}$} & \multirow[b]{2}{*}{$\mathrm{N}$} & \multirow[b]{2}{*}{ F-test } \\
\hline & & $\overline{\Delta \mathrm{GDP}}$ & Liber & $\Delta$ Trade & Free & Control & Foreign & Law & 100*Turn & Governance & Size & Industry & & & \\
\hline \multicolumn{16}{|c|}{ Panel A. DROS } \\
\hline (i) & $\begin{array}{l}0.097 \\
(0.64)\end{array}$ & $\begin{array}{l}0.006^{*} \\
(4.13)\end{array}$ & $\begin{array}{l}0.050^{* *} \\
(2.23)\end{array}$ & $\begin{array}{l}-0.039 \\
(0.45)\end{array}$ & & $\begin{array}{l}0.110^{*} \\
(4.44)\end{array}$ & & $\begin{array}{l}0.066 \\
(1.31)\end{array}$ & $\begin{array}{l}0.024 \\
(0.24)\end{array}$ & & $\begin{array}{l}-0.013 \\
(1.26)\end{array}$ & Included & 0.24 & 140 & $5.03^{*}$ \\
\hline (ii) & $\begin{array}{l}0.075 \\
(0.67)\end{array}$ & $\begin{array}{l}0.005^{*} \\
(3.33)\end{array}$ & & & $\begin{array}{l}0.002 \\
(0.14)\end{array}$ & $\begin{array}{l}0.115^{*} \\
(4.16)\end{array}$ & $\begin{array}{c}0.063^{* *} \\
(2.01)\end{array}$ & & $\begin{array}{l}0.031 \\
(0.26)\end{array}$ & & $\begin{array}{l}-0.012 \\
(1.06)\end{array}$ & Included & 0.23 & 121 & $4.65^{*}$ \\
\hline (iii) & $\begin{array}{l}-0.006 \\
(0.10)\end{array}$ & $\begin{array}{l}0.005^{*} \\
(3.17)\end{array}$ & & $\begin{array}{l}0.047 \\
(0.48)\end{array}$ & & $\begin{array}{l}0.115^{*} \\
(4.16)\end{array}$ & $\begin{array}{c}0.063^{* 1 * *} \\
(1.90)\end{array}$ & & & $\begin{array}{l}0.006 \\
(0.69)\end{array}$ & $\begin{array}{l}-0.011 \\
(1.15)\end{array}$ & Included & 0.23 & 121 & $4.67^{*}$ \\
\hline \multicolumn{16}{|c|}{ Panel B. DSALEFF } \\
\hline (i) & $\begin{array}{l}-0.781 \\
(0.75)\end{array}$ & $\begin{array}{l}0.017 \\
(1.42)\end{array}$ & $\begin{array}{c}0.447 * \\
(3.17\end{array}$ & $\begin{array}{l}0.766 \\
(1.28)\end{array}$ & & $\begin{array}{l}0.458^{*} \\
(3.55)\end{array}$ & & $\begin{array}{l}0.089 \\
(0.30)\end{array}$ & $\begin{array}{l}1.296^{\text {*k }} \\
(2.01)\end{array}$ & & $\begin{array}{l}-0.074 \\
(1.14)\end{array}$ & Included & 0.28 & 102 & $4.65^{*}$ \\
\hline (ii) & $\begin{array}{l}-0.510 \\
(0.99)\end{array}$ & $\begin{array}{l}0.021^{*}+* \\
(1.72)\end{array}$ & & & $\begin{array}{l}0.156^{*} \\
(2.58)\end{array}$ & $\begin{array}{l}0.396^{*} \\
(2.71)\end{array}$ & $\begin{array}{l}0.115 \\
(0.81)\end{array}$ & & $\begin{array}{l}1.513^{* *} \\
(2.07)\end{array}$ & & $\begin{array}{l}-0.078 \\
(1.29)\end{array}$ & Included & 0.27 & 91 & $4.29^{*}$ \\
\hline (iii) & $\begin{array}{l}-1.799 \text { *k } \\
(2.10)\end{array}$ & $\begin{array}{l}0.011 \\
(0.84)\end{array}$ & & $\begin{array}{l}1.152^{*} \\
(2.79)\end{array}$ & & $\begin{array}{l}0.478^{*} \\
(3.16)\end{array}$ & $\begin{array}{l}0.102 \\
(0.62)\end{array}$ & & & $\begin{array}{l}0.146^{*} \\
(3.74)\end{array}$ & $\begin{array}{l}-0.044 \\
(0.78)\end{array}$ & Included & 0.15 & 91 & $2.60^{*}$ \\
\hline
\end{tabular}


William Davidson Institute Working Paper 419

Table 9- Continued

\begin{tabular}{|c|c|c|c|c|c|c|c|c|c|c|c|c|c|c|c|}
\hline & \multirow[b]{2}{*}{ Const } & \multicolumn{4}{|c|}{$\begin{array}{c}\text { Economic Reforms and } \\
\text { Environment }\end{array}$} & \multicolumn{5}{|c|}{ Corporate Governance } & \multicolumn{2}{|c|}{ Control } & \multirow[b]{2}{*}{$A d j-R^{2}$} & \multirow[b]{2}{*}{$\mathrm{N}$} & \multirow[b]{2}{*}{ F-test } \\
\hline & & $\overline{\Delta G D P}$ & Liber & $\Delta$ Trade & Free & Control & Foreign & Law & 100*Turn & Governance & Size & Industry & & & \\
\hline \multicolumn{16}{|c|}{ Panel C. DCESA } \\
\hline (i) & $\begin{array}{l}-0.112 \\
(0.26)\end{array}$ & $\begin{array}{c}-0.001 \\
(0.48)\end{array}$ & $\begin{array}{l}0.082 \\
(0.64)\end{array}$ & $\begin{array}{l}0.195 \\
(1.15)\end{array}$ & & $\begin{array}{l}0.108 \\
(1.31)\end{array}$ & & $\begin{array}{l}0.105 \\
(1.00)\end{array}$ & $\begin{array}{l}-0.067 \\
(0.48)\end{array}$ & & $\begin{array}{l}-0.005 \\
(0.22)\end{array}$ & Included & 0.00 & 109 & 1.00 \\
\hline (ii) & $\begin{array}{l}-0.207 \\
(1.05)\end{array}$ & $\begin{array}{c}-0.001 \\
(0.82)\end{array}$ & & & $\begin{array}{c}0.093 \\
((1.49)\end{array}$ & $\begin{array}{l}0.155 \\
(1.30)\end{array}$ & $\begin{array}{l}0.054 \\
(0.65)\end{array}$ & & $\begin{array}{l}-0.120 \\
(0.88)\end{array}$ & & $\begin{array}{l}-0.015 \\
(0.58)\end{array}$ & Included & 0.05 & 96 & 1.55 \\
\hline (iii) & $\begin{array}{l}-0.519 \\
(1.57)\end{array}$ & $\begin{array}{c}-0.004 \\
(1.13)\end{array}$ & & $\begin{array}{c}0.394^{* 1 * k} \\
(1.85)\end{array}$ & & $\begin{array}{l}0.152 \\
(1.29)\end{array}$ & $\begin{array}{l}0.091 \\
(0.82)\end{array}$ & & & $\begin{array}{l}0.053 \\
(1.44)\end{array}$ & $\begin{array}{r}-0.012 \\
(0.55)\end{array}$ & Included & 0.02 & 96 & 1.16 \\
\hline \multicolumn{16}{|c|}{ Panel D. DSAL } \\
\hline (i) & $\begin{array}{c}-0.109 \\
(0.10)\end{array}$ & $\begin{array}{l}0.004 \\
(0.91)\end{array}$ & $\begin{array}{l}0.315^{*} \\
(2.51)\end{array}$ & $\begin{array}{l}0.358 \\
(0.73)\end{array}$ & & $\begin{array}{l}0.338^{*} \\
(2.81)\end{array}$ & & $\begin{array}{l}0.258 \\
(0.74)\end{array}$ & $\begin{array}{c}1.245^{\text {*kk }} \\
(1.80)\end{array}$ & & $\begin{array}{l}-0.075 \\
(1.05)\end{array}$ & Included & 0.17 & 140 & 3.58* \\
\hline (ii) & $\begin{array}{c}-0.162 \\
(0.28)\end{array}$ & $\begin{array}{l}0.007 \\
(1.66)\end{array}$ & & & $\begin{array}{l}0.157^{*} \\
(3.17)\end{array}$ & $\begin{array}{l}0.358^{*} \\
(2.99)\end{array}$ & $\begin{array}{l}-0.008 \\
(0.10)\end{array}$ & & $\begin{array}{c}1.266^{\text {kk* }} \\
(1.65)\end{array}$ & & $\begin{array}{l}-0.084 \\
(1.15)\end{array}$ & Included & 0.17 & 122 & $3.40^{*}$ \\
\hline (iii) & $\begin{array}{l}-1.431 \\
(0.20)\end{array}$ & $\begin{array}{c}-0.003 \\
(0.47)\end{array}$ & & $\begin{array}{l}1.053^{*} \\
(3.84)\end{array}$ & & $\begin{array}{l}0.348^{*} \\
(3.11)\end{array}$ & $\begin{array}{l}0.074 \\
(0.45)\end{array}$ & & & $\begin{array}{l}0.139 * \\
(4.17)\end{array}$ & $\begin{array}{l}-0.047 \\
(0.72)\end{array}$ & Included & 0.08 & 122 & $1.98^{* *}$ \\
\hline
\end{tabular}




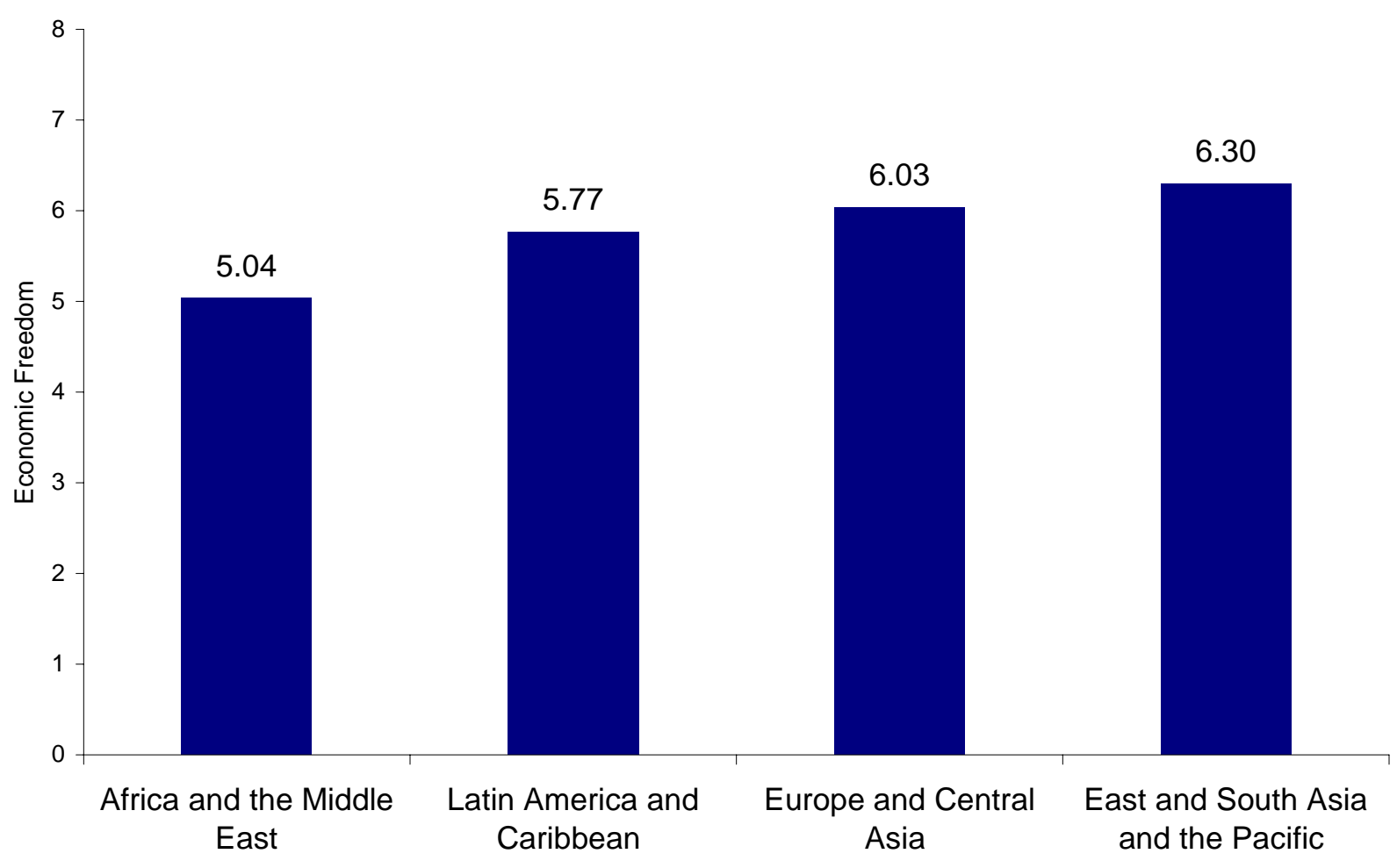

Figure 1. Economic Freedom by Geographical Region (1980-97)

The figure presents the mean level of the economic freedom index over the period 1980-1997 for the four geographical regions included in our sample. The classification of geographical regions follows the World Bank country group classification. Data are from Gwartney, Lawson and Samida (2000). The index is a range of objective components that reflect the presence (or absence) of economic freedom. The scale is from 0 to 10, with higher scores indicating higher levels of economic freedom. 


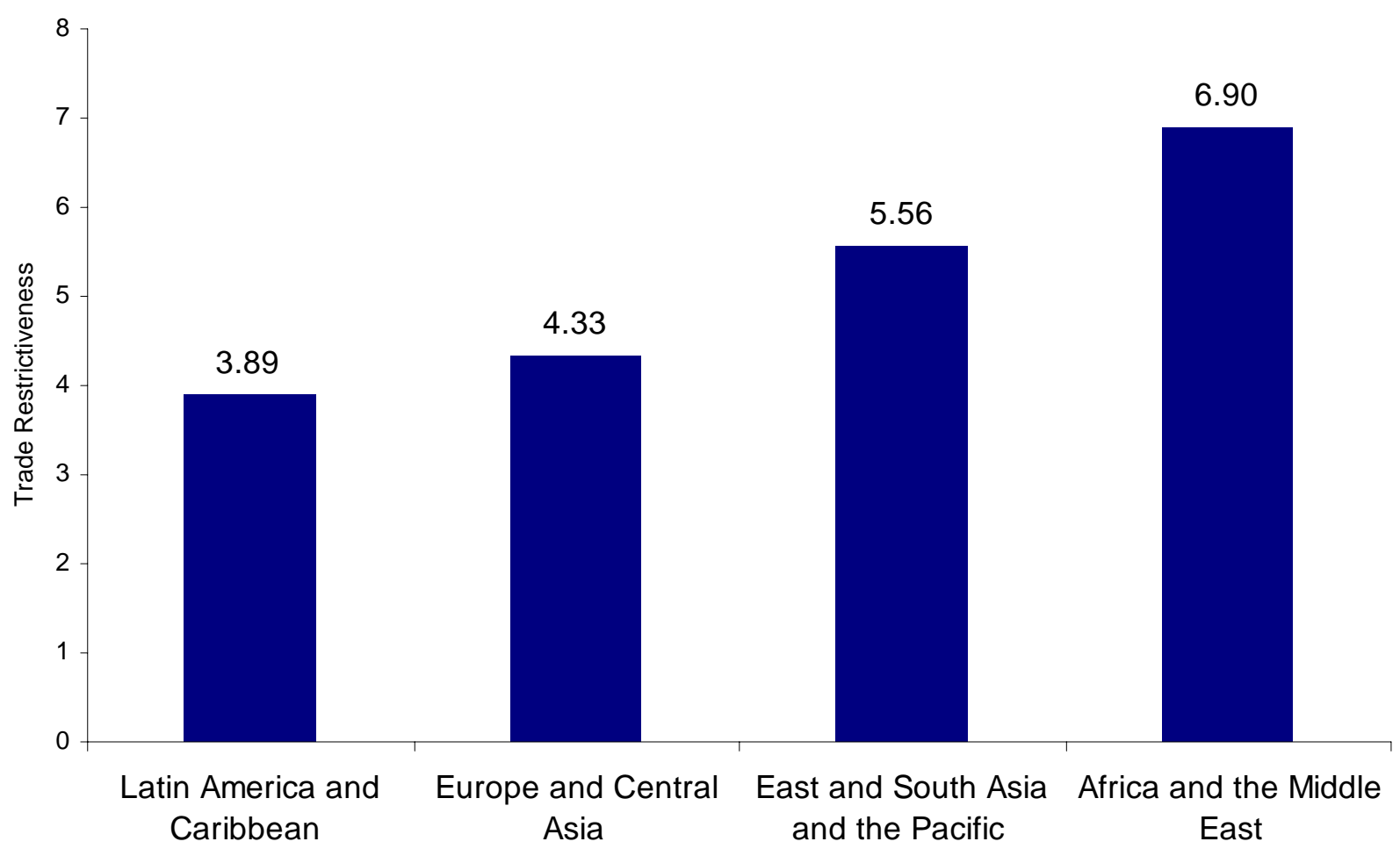

Figure 2. Trade Restrictiveness Index by Geographical Region (1997)

The figure reports the 1997 value of the trade restrictiveness developed by the International Monetary Fund for the four geographical regions included in our sample. The classification of geographical regions follows the World Bank country group classification. Higher index scores imply more trade restrictiveness. 


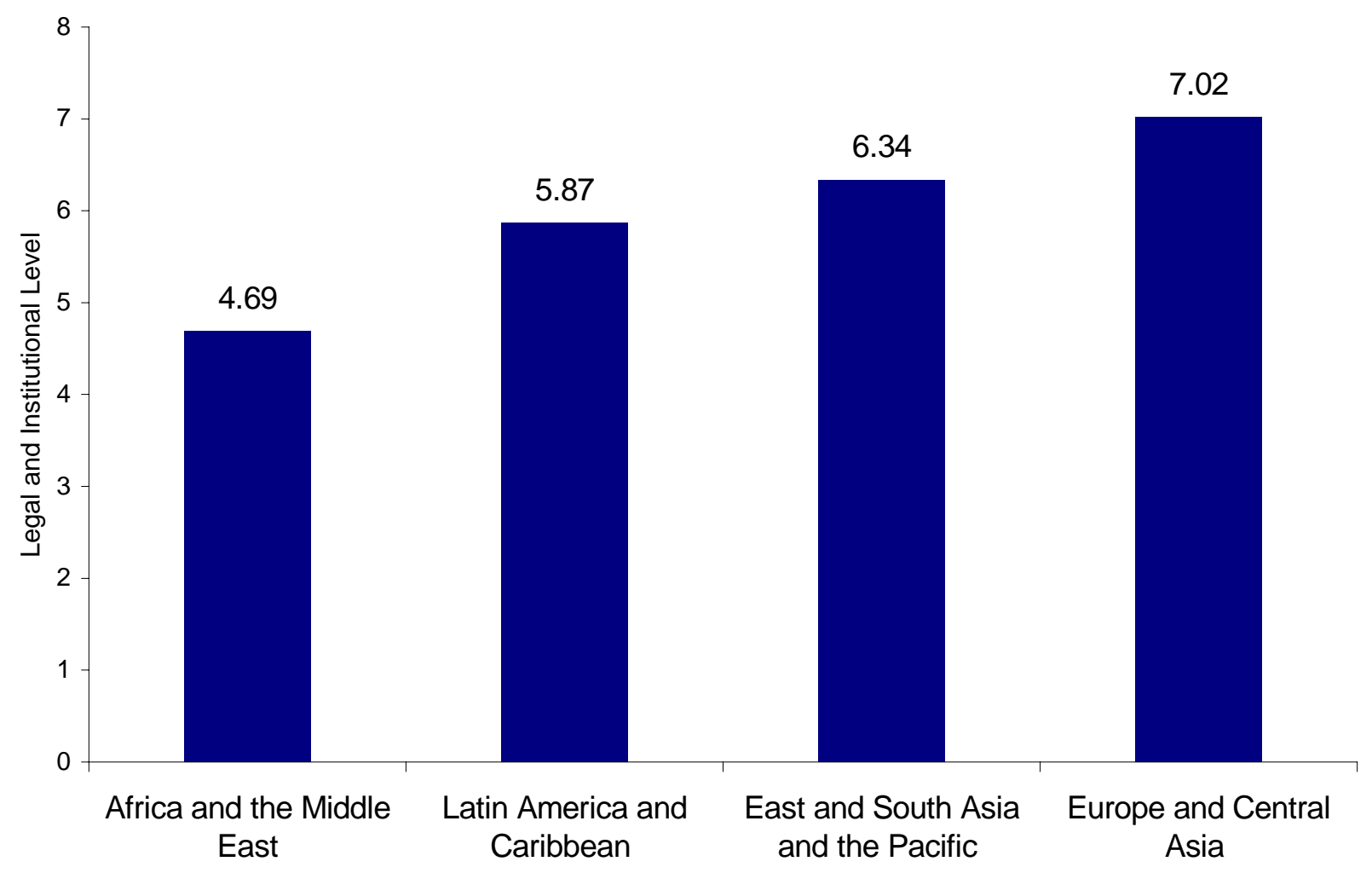

\section{Figure 3. Governance Index by Geographical Region (1980-97)}

The figure reports the average scores of the governance index over the period 1980-1997 for the four geographical regions included in our sample. The classification of geographical regions follows the World Bank country group classification. Data are from Gwartney, Lawson and Samida (2000). The index focuses on the legal structure and the security of property rights and the enforcement of contracts. The scale is from 0 to 10, with higher scores indicating higher levels of legal protection and law enforcement. 


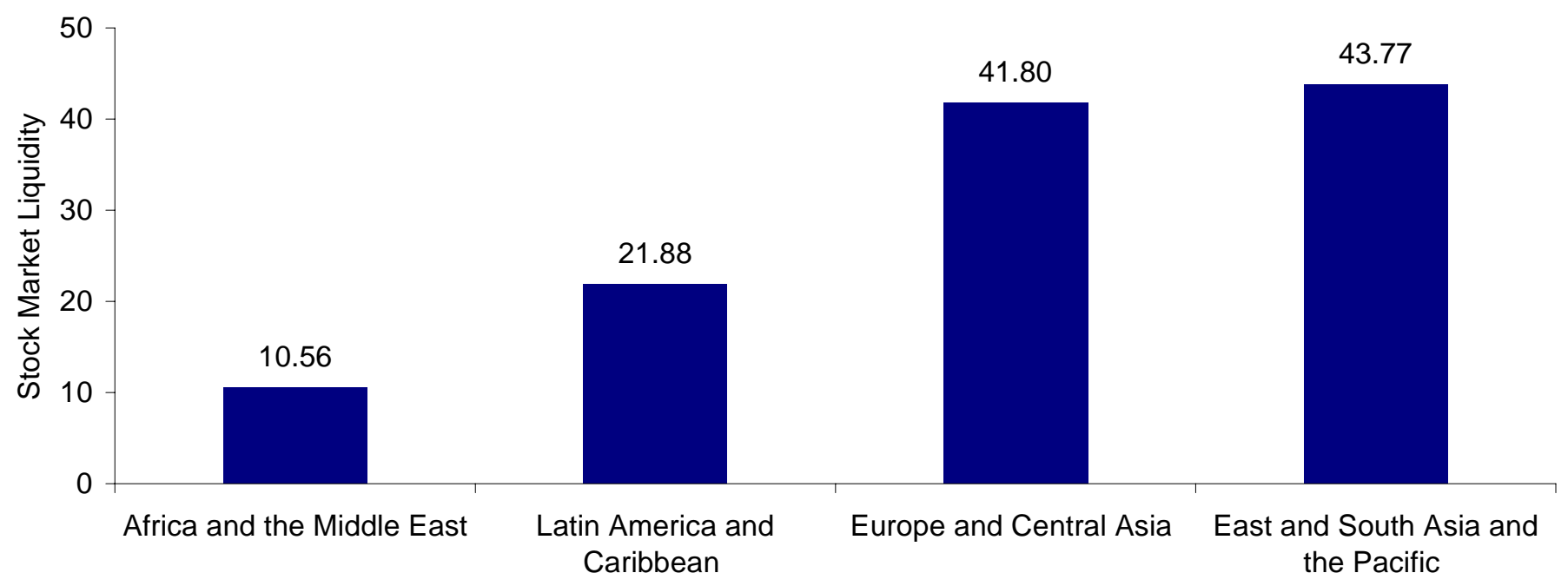

Figure 4. Stock Market Liquidity by Geographical Region (1980-97)

The figure depicts the level of stock market liquidity measured by the average turnover ratio over the period 1980-97 for the four geographical regions included in our sample. The classification of geographical regions follows the World Bank country group classification. Data are from the World Development Indicators (2001) CD-ROM . 


\section{DAVIDSON INSTITUTE WORKING PAPER SERIES - Most Recent Papers}

The entire Working Paper Series may be downloaded free of charge at: www.wdi.bus.umich.edu

CURRENT AS OF 12/17/01

\begin{tabular}{|c|c|c|}
\hline Publication & Authors & Date \\
\hline $\begin{array}{l}\text { No. 419: Liberalization, Corporate Governance, and the Performance of } \\
\text { Newly Privatized Firms }\end{array}$ & $\begin{array}{l}\text { Narjess Boubakri, Jean-Claude } \\
\text { Cosset, and Omrane Guedhami }\end{array}$ & Dec. 2001 \\
\hline $\begin{array}{l}\text { No. 418: The European Data Privacy Directive and International } \\
\text { Relations }\end{array}$ & Steven R. Salbu & Dec. 2001 \\
\hline $\begin{array}{l}\text { No. 417: Capital Markets and Capital Allocation: Implications for } \\
\text { Economies in Transition }\end{array}$ & $\begin{array}{l}\text { Artyom Durnev, Randall Morck, } \\
\text { and Bernard Yeung }\end{array}$ & Dec. 2001 \\
\hline $\begin{array}{l}\text { No. } 416 \text { Forthcoming in: The Journal of Economic Perspectives, "Data } \\
\text { Watch. Research Data from Transition Economies." }\end{array}$ & $\begin{array}{l}\text { Randall K. Filer and Jan } \\
\text { Hanousek }\end{array}$ & Dec. 2001 \\
\hline $\begin{array}{l}\text { No. } 415 \text { Forthcoming in: The Journal of Economic Perspectives, } \\
\text { "Transition Economies: Performance and Challenges." }\end{array}$ & Jan Svejnar & Dec. 2001 \\
\hline $\begin{array}{l}\text { No. } 414 \text { Forthcoming in: The Journal of Economic Perspectives, "The } \\
\text { Great Divide and Beyond: Financial Architecture in Transition." }\end{array}$ & Erik Berglof and Patrick Bolton & Dec. 2001 \\
\hline $\begin{array}{l}\text { No. } 413 \text { Forthcoming in: The Journal of Economic Perspectives, "The } \\
\text { Political Economy of Transition." }\end{array}$ & Gérard Roland & Dec. 2001 \\
\hline $\begin{array}{l}\text { No. 412: The Response of Consumption in Russian Households to } \\
\text { Economic Shocks }\end{array}$ & Steven Stillman & Oct. 2001 \\
\hline No. 411: Mark-ups in Hungarian Corporate Sector & László Halpern and Gábor Körösi & Aug. 2001 \\
\hline No. 410: Economic Development, Legality, and the Transplant Effect & $\begin{array}{l}\text { Daniel Berkowitz, Katarina } \\
\text { Pistor, Jean-Francois Richard }\end{array}$ & Sept. 2001 \\
\hline No. 409: Development Strategy, Viability, and Economic Convergence & Justin Yifu Lin & Oct. 2001 \\
\hline No. 408: Labor Supply, Informal Economy and Russian Transition & Maxim Bouev & May 2001 \\
\hline No. 407: Corporate Governance in China: Then and Now & Cindy Schipani and Liu Junhai & Nov. 2001 \\
\hline No. 406: Entrepreneurship and Post-Socialist Growth & $\begin{array}{l}\text { Daniel Berkowitz and David N. } \\
\text { DeJong }\end{array}$ & Oct. 2001 \\
\hline $\begin{array}{l}\text { No. } 405 \text { Forthcoming in: European Economic Review, "Policy Reform } \\
\text { and Growth in Post-Soviet Russia." }\end{array}$ & $\begin{array}{l}\text { Daniel Berkowitz and David N. } \\
\text { DeJong }\end{array}$ & Oct. 2001 \\
\hline $\begin{array}{l}\text { No. 404: Social Policies and Structures: Institutional Frictions and Traps } \\
\text { in the Czech Republic after } 1989\end{array}$ & Jiří Večerník & Nov. 2001 \\
\hline $\begin{array}{l}\text { No. 403: Investment, Efficiency, and Credit Rationing: Evidence from } \\
\text { Hungarian Panel Data }\end{array}$ & Mathilde Maurel & Nov. 2001 \\
\hline $\begin{array}{l}\text { No. 402: Subduing High Inflation in Romania. How to Better Monetary } \\
\text { and Exchange Rate Mechanisms? }\end{array}$ & $\begin{array}{l}\text { Daniel Daianu and Radu } \\
\text { Vranceanu }\end{array}$ & Aug. 2001 \\
\hline $\begin{array}{l}\text { No. 401: The Gender Wage Gap in Bulgaria: A Semiparametric } \\
\text { Estimation of Discrimination }\end{array}$ & Dean Jolliffe & July 2001 \\
\hline $\begin{array}{l}\text { No. 400: Do External Auditors Perform a Corporate Governance Role in } \\
\text { Emerging Markets? Evidence from East Asia }\end{array}$ & Joseph P. H. Fan and T.J. Wong & Oct. 2001 \\
\hline $\begin{array}{l}\text { No. 399: Financial Conditions and Investment during the Transition: } \\
\text { Evidence from Czech Firms }\end{array}$ & Lubomír Lízal and Jan Svejnar & Oct. 2001 \\
\hline $\begin{array}{l}\text { No. 398: Accessible Pareto-Improvements: Using Market Information to } \\
\text { Reform Inefficiencies }\end{array}$ & Michael Mandler & May 2001 \\
\hline No. 397: The Making of an Integrated National Grain Market in China & Wubiao Zhou & Oct. 2001 \\
\hline No. 396: Corruption and Resource Allocation: Evidence from China & Wei Li & June 2001 \\
\hline $\begin{array}{l}\text { No. 395: Government Shareholding and the Value of China's Modern } \\
\text { Firms }\end{array}$ & Lihui Tian & Apr. 2001 \\
\hline No. 394: Labor Hoarding in Russia: Where Does it Come from? & $\begin{array}{l}\text { Rouslan Koumakhov and Boris } \\
\text { Najman }\end{array}$ & June 2000 \\
\hline $\begin{array}{l}\text { No. 393: Ownership Structure, Corporate Governance, And Firm Value: } \\
\text { Evidence from the East Asian Financial Crisis }\end{array}$ & Michael Lemmon and Karl Lins & Apr. 2001 \\
\hline
\end{tabular}

